
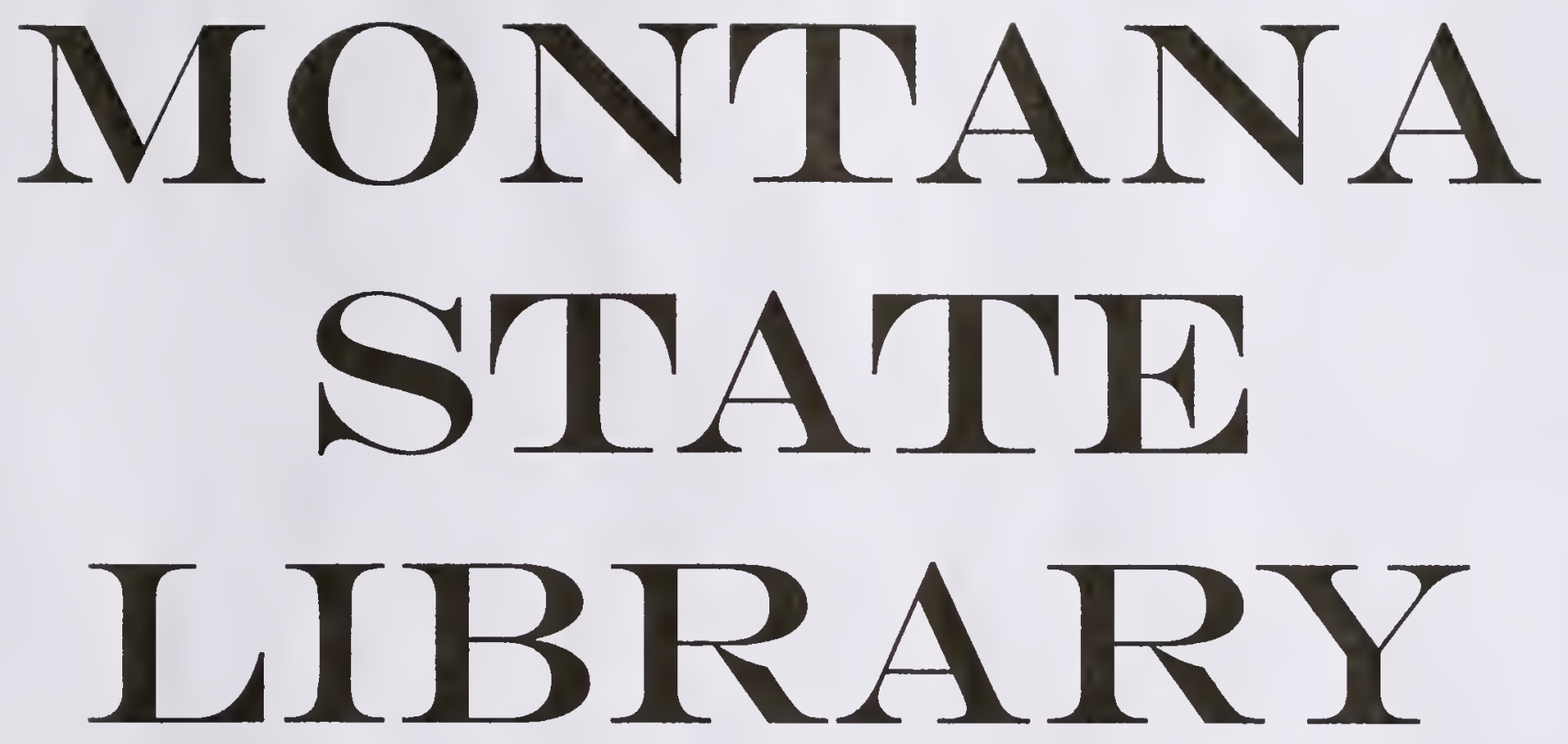


\title{
DISTRIBUTION, RELATIVE ABUNDANCE AND HABITAT UTILIZATION \\ OF THE ARCTIC GRAYLING (THYMALLUS ARCTICUS) \\ IN THE UPPER BIG HOLE RIVER DRAINAGE, MONTANA \\ JULY 5 TO SEPTEMBER 8,1988
}

by

Don Skaar

Montana Natural Heritage Program

1515 East Sixth Avenue

Helena, Montana 59620

\author{
for the \\ Montana Natural Heritage Program \\ Beaverhead National Forest \\ Montana Department of Fish, Wildlife and Parks \\ Montana Cooperative Fishery Research Unit
}

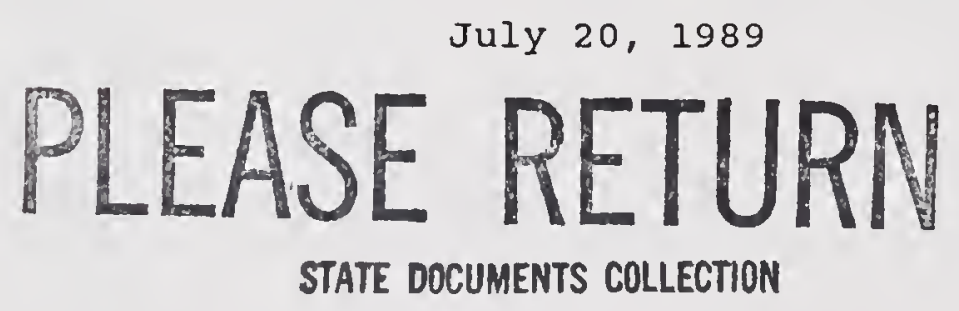

\section{MAR 121990}

MONTANA STATE LIBRARY

1515 E. 6th AVE.

HELENA, MONTANA 59620 
CONTENTS

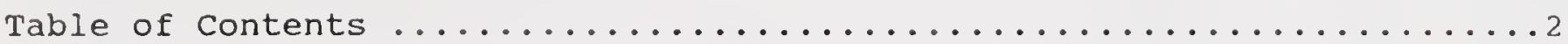

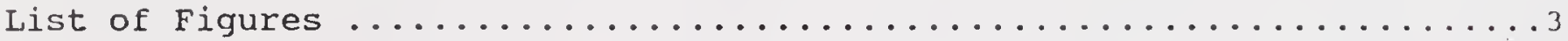

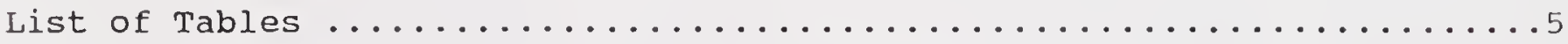

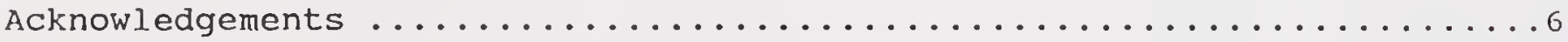

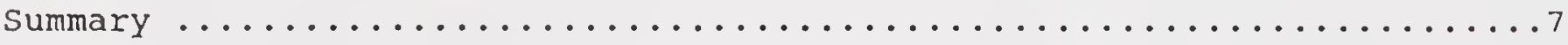

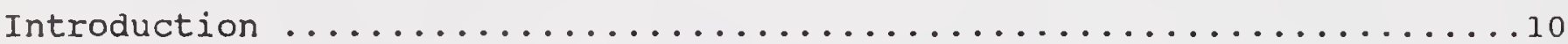

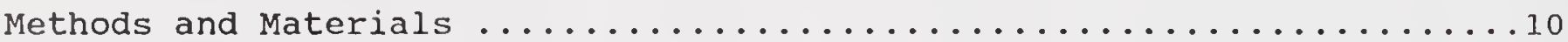

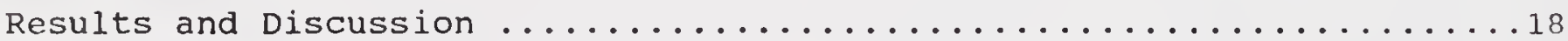

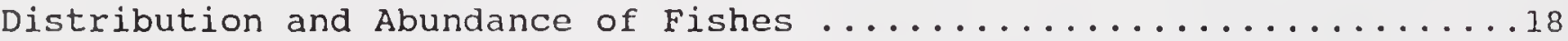

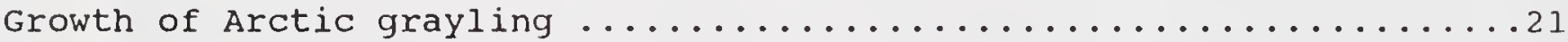

Habitat Utilization by Young-of-the-Year Arctic grayling .......25

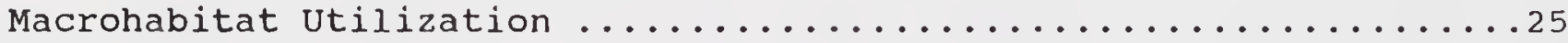

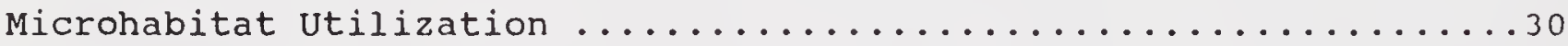

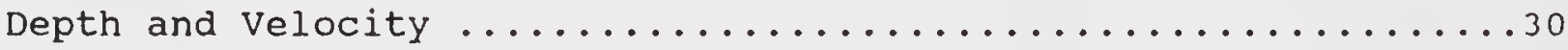

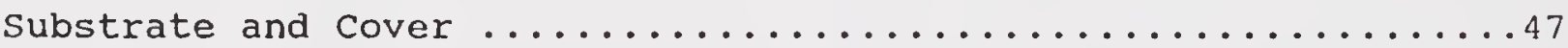

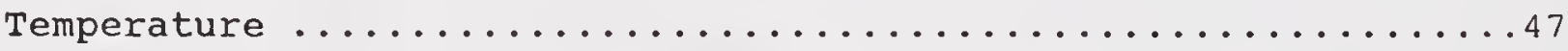

Reliability and Applicability of Microhabitat Measurements .....49

Transferability of Utilization Criteria to other streams ......50 Movements of Young-of-the-Year Arctic grayling in Their First Summer 51

Interactions Between Arctic Grayling and Brook Trout ..........51

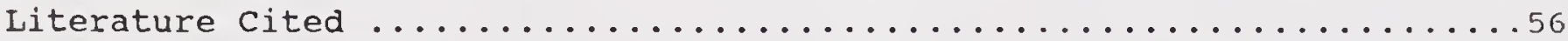




\section{LIST OF FIGURES}

Number

Page

1 Map of the upper Big Hole River drainage, showing sample sections where electrofishing surveys were conducted ..................11

2 Example of the transect-grid system used to measure habitat

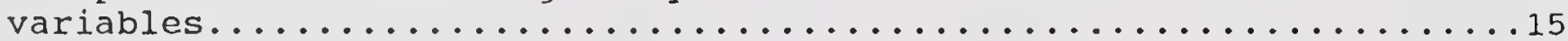

3 Mean, standard deviation and range of total length of Arctic grayling in the Big Hole River, July 7 -September 1, $1988 \ldots \ldots \ldots$

4 Length-frequency distribution of age 1 and older Arctic grayling in the upper Big Hole River drainage in July (A)

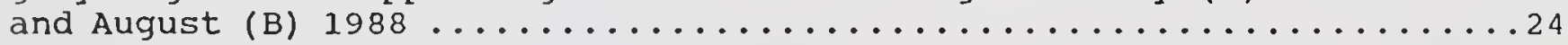

5 Frequency of depth measurements at capture sites of young-of-the-

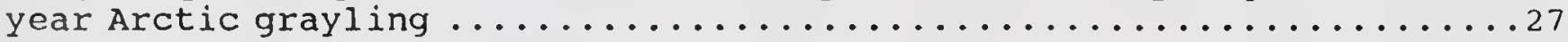

6 Frequency of mean velocity measurements at capture sites of young-

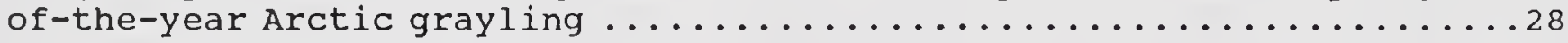

7 Frequency of depth measurements over $0.1 \mathrm{ft}$ in areas near young-ofthe-year Arctic grayling capture sites .......................

8 Frequency of mean velocity measurements in areas near young-of-theyear Arctic grayling capture sites in water over $0.1 \mathrm{ft}$ deep ......32

9 Depth (ft) isopleths for intensive-use area "A" on Swamp Creek.......34

10 Mean velocity $(\mathrm{ft} / \mathrm{s})$ isopleths for intensive-use area "A" on Swamp

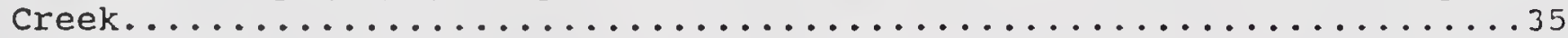

11 Depth (ft) isopleths for intensive-use area "B" on the Big Hole

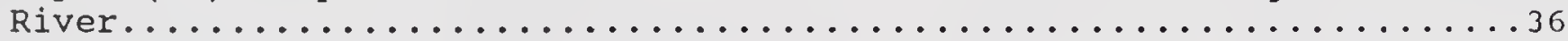

12 Mean velocity (ft/s) isopleths for intensive-use area "B" on the Big Hole River ..........................................

13 Depth (ft) isopleths for intensive-use area "C" on the Big Hole

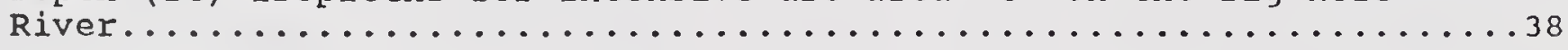

14 Mean velocity (ft/s) isopleths for intensive-use area "C" on the Big

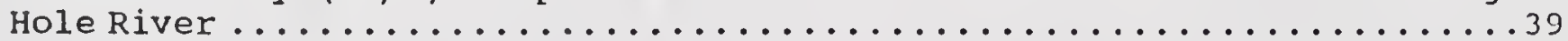

15 Depth (ft) isopleths for intensive-use area "D" on the Big Hole

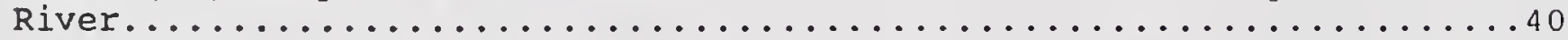

16 Mean velocity (ft/s) isopleths for intensive-use area "D" on the Big Hole River ......................................41 
17 Physical features of intensive-use area "A" on Swamp Creek, indicating usable area (area delimited by shading) for YOY Arctic

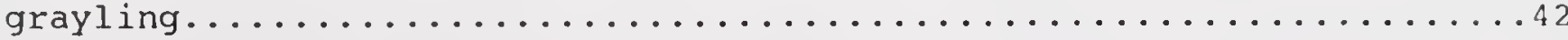

18 Physical features of intensive-use area "B" on the Big Hole River, indicating usable area (area delimited by shading) for YoY Arctic

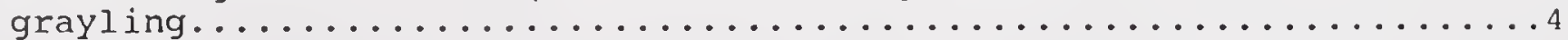

19 Physical features of intensive-use area " $C$ " on the Big Hole River, indicating usable area (area delimited by shading) for YoY Arctic grayling........................................... 44

20 Physical features of intensive-use area "D" on the Big Hole River, indicating usable area (area delimited by shading) for YOY Arctic

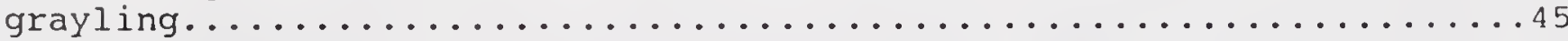

21 Locations where young-of-the-year Arctic grayling were captured in Swamp Creek and the east channel of the Big Hole River during July and August 1988 (open circles, which include number of fish captured), and locations where ripe or spent adult Arctic grayling were found in April and May 1988 (blackened areas) ............53

Scatterplot and linear regression of number of young-of-the-year brook trout fry vs. number of young-of-the-year Arctic grayling .....55 


\section{LIST OF TABLES}

Number

Page

1 Physical characteristics of sample sections in the study Area and

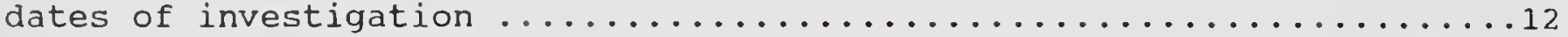

2 Total number and relative abundance of Arctic grayling and trout captured by electrofishing in the Big Hole River drainage, July 5 -

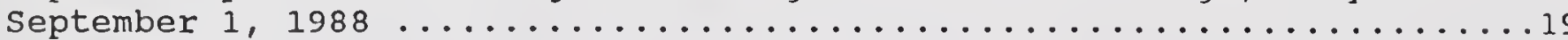

3 Relative abundance of mountain whitefish and non-game fish in the

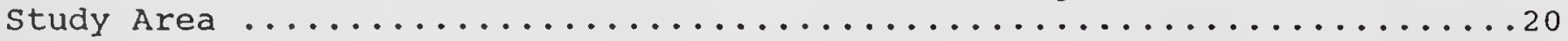

4 Mean and range of total length (in) of age 0 Arctic grayling and brook trout in the Big Hole River, July 7 - September 1, 1988 ......22

5 Macrohabitat features of Swamp creek and the east channel of the Big

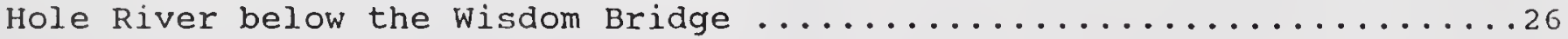

6 Mean values, 50\% utilization or availability limits, and ranges for habitat variables of habitat attributes at capture sites, at areas near capture sites and estimates for areas not measured ...........29

7 Incidence of cover types closest to capture sites and within a $3.28 \mathrm{ft}^{2}$ cell surrounding the capture site $\ldots \ldots \ldots \ldots \ldots \ldots \ldots \ldots$

8 Afternoon water temperatures in the Big Hole River and its tributaries, July 12 -September $7,1988 \ldots \ldots \ldots \ldots \ldots \ldots \ldots \ldots \ldots \ldots \ldots \ldots \ldots \ldots . \ldots \ldots$

9 A comparison of the distance (ft) from capture sites to the base of the nearest upstream riffle when the electrofishing crew worked upstream vs. downstream ............................. 
Funding for personnel for this study came from the Montana Natural Heritage Program (MNHP), the Beaverhead National Forest through the challenge cost-share program, and the Montana Cooperative Fishery Research Unit (MCFRU). The Montana Department of Fish, Wildlife and Parks (MDFWP) provided field equipment and transportation. The Wisdom Ranger District, Beaverhead National Forest, provided trailer space and use of their facilities as a base of operations for the field study. project, and Dave provided overall supervision for the oswald (MDFWP) provided (MNHP), Bill Gould (MCFRU) and Dick a co-worker in the field helpful advice. Gary senger (MCFRU) was methods and computer file fontributed to the development of provided help with the use of (MDFWP) helped on several of computer software. Greg Gibbons 


\section{SUMMARY}

This report documents investigations of the distribution, relative abundance and habitat utilization of Arctic grayling (Thymallus arcticus) and other fishes in selected segments of the upper Big Hole River, its tributaries and associated irrigation ditches from 5 miles north of Wisdom upstream to 7 miles south of Jackson during the period July 5 to september $8,1988$.

Electrofishing was used to document the distribution and relative abundance of fishes. Greatest concentrations of young-of-the-year (YOY) Arctic grayling were found in swamp Creek, the west channel of the Big Hole River above and below the wisdom bridge (including an irrigation ditch above the wisdom bridge) and the east channel of the Big Hole River below the Wisdom bridge. Older grayling followed this same pattern of occurrence, with three notable differences: 1) seven age It fish ( $<9$ inches) were found in Governor Creek; 2) no older fish were found in Swamp Creek; and 3) no older fish were found in the irrigation ditches.

Young-of-the-year brook trout (salvelinus fontinalis) were plentiful in two of the three upper sample sections (Nelson Lane and Dick Hirschy Ranch), the tributaries (steel, Swamp and Governor Creeks) and the east channel of the Big Hole River below the wisdom bridge. They were scarce in all other sample sections around the wisdom Bridge and absent in the irrigation ditches. older brook trout followed this same general pattern, except that older fish were plentiful in the uppermost sample section (Dooling Bridge).

Rainbow trout (oncorhynchus mykiss) were plentiful only in the uppermost sample section and in Governor creek. Only nine rainbow trout were found in lower sample sections of the drainage, and may have drifted down from upper portions of the drainage.

Other fish species captured in the study Area were white sucker (Catostomus commersoni), longnose sucker (Catostomus platyrhynchus), mottled sculpin (Cottus bairdi), burbot (Lota lota), mountain whitefish (Prosopium williamsoni), and longnose dace (Rhinichthys cataractae).

Mean total length ( \pm SD) of young-of-the-year Arctic grayling increased from $2.45 \pm 0.12$ inches to $4.26 \pm 0.37$ inches between July 7 and september $\overline{1}$. These fish were considerably longer than those measured by Liknes (1981) in 1979 at the same time of year and location; the reason for this may be related to higher water temperatures in 1988 than in 1979.

Length-frequency distribution of Arctic grayling over 6 inches was bimodal, with peaks at $7.0-8.5$ inches and 9.0-11.0 
inches, which corresponded to age I+ and II+ fish, respectively. Fish over 6 inches had a mean ( \pm SD) condition factor (K) value of $1.06 \pm 0.11$, somewhat higher than the mean value of $0.95 \pm$ 0.08 calculated by Liknes (1981) for fish in the same general area in 1979.

Electrofishing was used to characterize macro- and microhabitat utilization by young-of-the-year Arctic grayling for the east channel of the Big Hole River below the Wisdom bridge and for swamp creek. Considering the two areas collectively, fish were captured a mean distance of $24.9 \mathrm{ft}$ downstream from the base of riffles and were in fast water (rapids, low-gradient riffles or runs) at $81 \%$ of the capture sites, and in slow water (pools and slow runs) at 19\% of the capture sites. Wetted stream width at capture sites averaged $17.6 \mathrm{ft}$, while channel width averaged $70.6 \mathrm{ft}$, and bank height averaged $2.5 \mathrm{ft}$.

Young-of-the-year Arctic grayling were captured at depths ranging from 0.2 to $3.0 \mathrm{ft}$ in water with velocities ranging from 0.0 to $1.87 \mathrm{ft} / \mathrm{s}$. Data on habitat availability were collected only for areas near to capture sites, and an analysis of these suggested that depths and velocities utilized by the fish were limited relative to depths and velocities not used, and therefore may have been selected preferentially.

The types of substrate and percent of cover were estimated for a $3.28 \mathrm{ft}^{2}$ cell that was centered on the capture sites. Substrate was divided into 6 types: silt, sand, small gravel, large gravel, cobble and boulder, and all types except for boulders were found at the capture sites. On the average no substrate type predominated, and all types occupied between 15 and $26 \%$ of the cell. Cover, on the average, occupied $24 \%$ of the cell. Aquatic vegetation was by far the most abundant type of cover, and was found at $84.6 \%$ of the capture sites.

Information about the movements of young-of-the-year Arctic grayling in their first summer is largely circumstantial. A separate study in April and May 1988 looked for the locations of spawning Arctic grayling. Ripe or spent fish were found in many locations that were in close proximity to areas where concentrations of YOY fish were found in July and August. This suggests that at least some fish stayed close to their natal spawning gravels, but it cannot be ascertained if or how many fish were more mobile and moved away from these areas.

Site fidelity of young-of-the-year fish to riffles and runs was observed in five areas that were electrofished 14-29 days after the initial electrofishing survey. Forty-five YOY Arctic grayling were captured in these areas during the initial survey, while 33 were captured during the second survey. The fish were not marked, so it is not known if they were the same fish that 
were captured the first time. The fidelity to these areas persisted even though streamflow discharges dropped by about $20 \%$ between the times of the two inventories.

The possibility of interspecific competition between brook trout and Arctic grayling was investigated. Distinct differences in habitat utilization by age I and older fish were seen. Brook trout were most abundant in the higher gradient, upper sample sections of the Study Area, but were present throughout the study Area. In sample sections where both species occurred, there was a tendency for brook trout to occupy faster water, often in association with undercut banks or overhanging terrestrial vegetation. The brook trout were not restricted to this type of water, however, and were found in lesser numbers in typical grayling habitat as well, which was slow runs or pools with depths typically at least 2-3 ft. Often, the pools could be characterized as backwater areas with foam on the water surface. Differences in habitat utilization by young-of-the-year fish were also seen. In areas where high densities of Arctic grayling fry were found, brook trout fry tended to occupy a wider range of habitats than the grayling--using areas ranging from slow, shallow runs to fast riffles. Occasionally the two species were found in the same areas. The possibility of spatial segregation by the two species of fry was investigated by Iinear regression analysis. Although the negative correlation was not significant, there was a tendency for one of the species to be in low numbers if the other species was in high numbers. 


\section{INTRODUCTION}

The historic distribution of the Arctic grayling (Thymallus arcticus) in Montana included the Missouri River and its tributaries above the Great Falls (Liknes 1981). Today, the only substantial stream-dwelling population in the United states outside of Alaska is in the upper Big Hole River drainage. Concern for the well-being of this population has increased in recent years. Liknes (1981) suggested that dewatering, overexploitation and interspecific competition may be factors that contributed to the disappearance of the Arctic grayling from most of its historic range and may be acting on the upper Big Hole River population as well. The Montana Department of Fish, wildlife and Parks (MDFWP) has made spring and fall estimates of the population since 1983, and over this time has seen an apparent decline in relative abundance in the wisdom area (Dick oswald and Brad Shepard, pers. comm.).

Early in 1988, the Montana Natural Heritage Program, the Montana Department of Fish, Wildlife and Parks, the Montana Cooperative Fishery Research Unit, and the U.S. Forest Service entered into a cooperative study of the age-specific habits and habitat requirements of the Arctic grayling in the upper Big Hole River drainage during the spring-summer-fall periods. This report provides the results from a portion of that study, which sought to obtain detailed information on the summer distribution and habitat preferences of Arctic grayling in the Wisdom-Jackson area, with emphasis placed on young-of-the-year fish.

\section{METHODS AND MATERIALS}

Selected segments of the upper Big Hole River, its tributaries, and associated irrigation ditches were electrofished from July 5 to september 1, 1988 to document the distribution and relative abundance of Arctic grayling. The segments were assigned to "sample sections", which were discrete portions of a stream, usually bordered up and downstream by non-electrofished areas, but sometimes separated from adjacent electrofishing sample sections by prominent physical features (Figure 1). Sample sections ranged in length from 0.60 to $3.49 \mathrm{miles,}$ gradient from 0.18 to $1.05 \%$, and discharge from less than 1 to $25-30 \mathrm{ft}^{3} / \mathrm{s}$ (Table 1 ).

A two- or three-man crew worked with two mobile-electrode electrofishing systems: a cofellt BP-IC backpack system typically operated on non-pulsed direct current at 100 watts of power, and a plastic flat-bottomed boat outfitted with a 240 watt gasoline-powered AC generator with a Harvey Leach rectifying unit to convert current to non-pulsed or pulsed direct current. The boat-mounted system was used primarily on the Big Hole River 


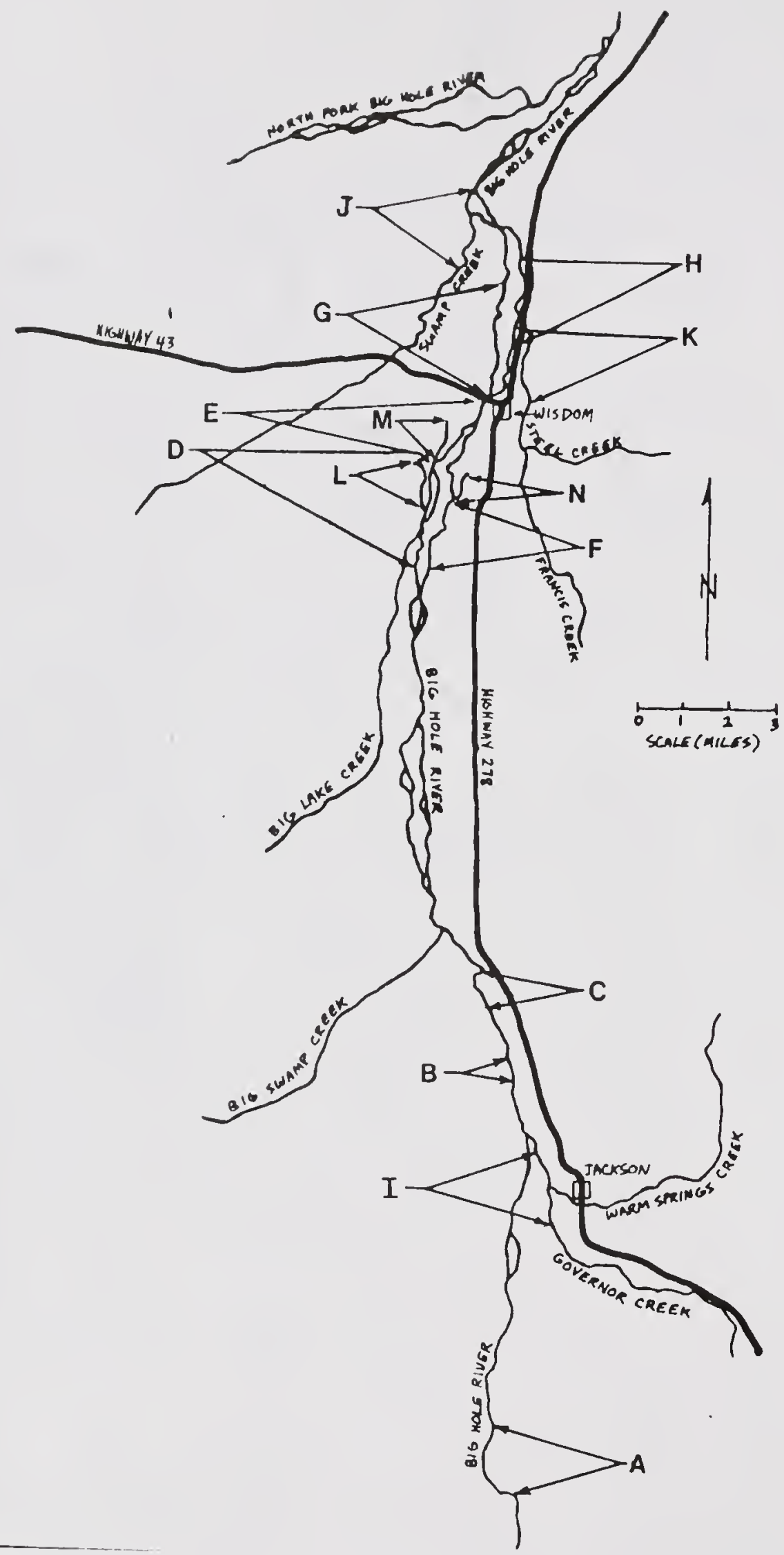




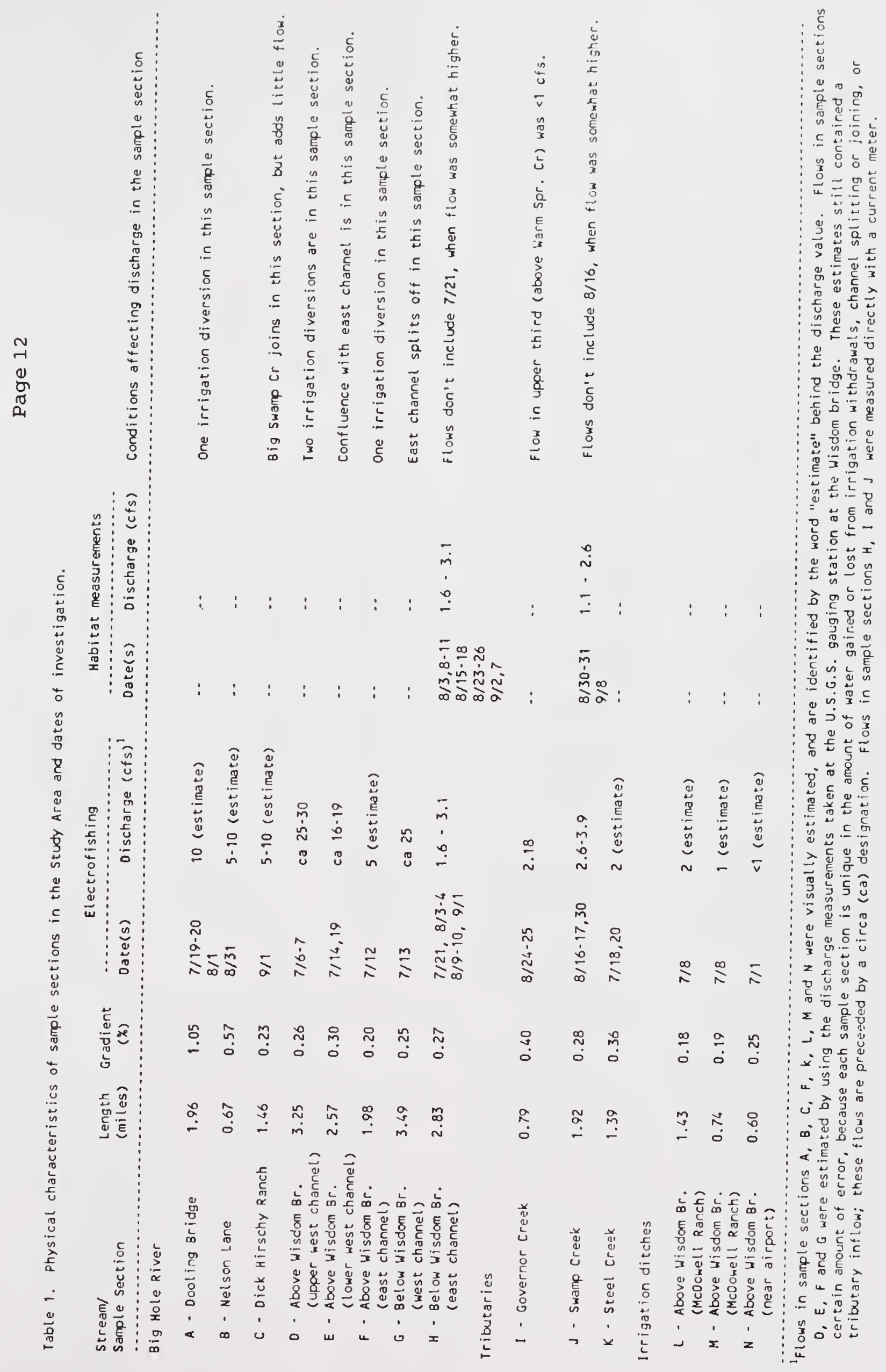


during the higher flow periods in July, while the backpack system was used on the river during low flow periods in August and on tributaries and irrigation ditches. Electrofishing proceeded downstream when the boat system was used, and proceeded either upstream or downstream when the backpack system was used.

Electrofishing sessions typically lasted $1 / 2$ - 1 hour, and the area covered during this time was referred to as a "sub-section." only Arctic grayling and trout were captured, and stunned fish were placed in a live car until the end of the sub-section. Lengths and weights of captured $f i s h$ were measured to the nearest 0.1 inch (TL) and 0.01 pound, respectively. Scales were taken from all age $I$ and older Arctic grayling and rainbow trout, and all fish over 8 inches $T L$ were tagged with a floy anchor tag. In some cases where brook trout densities were particularly high, stunned brook trout were not captured, but instead were counted and visually grouped into one of three categories: 1) young-of-the-year (YOY): 2) under 6 inches TL, but not YOY; and 3) over 6 inches TI. The relative abundance of other fish species was also visually estimated for each sub-section, using the following scale: "few" = 1-10 individuals, "some" = 11-25 individuals, "many" = 26-50 individuals, and "abundant" $=51+$ individuals.

Although lengths and weights of $\mathrm{fish}$ were recorded in English units, they were converted to metric units to make a comparison with condition factors (K) generated by Liknes (198I). $K$ values were determined using the equation:

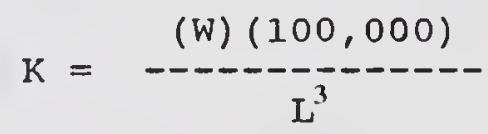

where $\mathrm{W}=$ weight in grams and $\mathrm{L}=$ length in millimeters.

Macro- and microhabitat utilization by young-of-the-year Arctic grayling was determined for the east channel of the Big Hole River below the wisdom Bridge (sample section $H$ ) and for Swamp creek (sample section $J$ ). The objective of the macrohabitat measurements was to characterize general stream features with which the YOY fish were associated, including bank height, stream width, pool and riffle size, and bank condition. The objective of the microhabitat measurements was to characterize depth, velocity, substrate, cover, and distance to cover at the central part of the home range (focal points) of the age $0+$ fish.

Focal points were determined during the normal process of the electrofishing surveys. The backpack electrofishing system was used, typically operated at 100-150 watts by a two- or three-man crew. The typical approach was to walk in the water (working either upstream or downstream), with the person 
operating the backpack electrode slighty in front of the netter. The backpack operator would quickly stab the water with the electrode in an effort to keep the durations of electrical current to a minimum and to avoid herding or spooking the fish. When fish were captured, the sites were marked with a rock wrapped with yellow or fluorescent orange flagging. If mass fish movement was seen, or if it was felt for any other reason that the fish had moved in response to the presence of the crew, then habitat measurements were not taken from that capture site.

This sampling strategy attempted to avoid three types of bias that can occur when investigating microhabitat use: 1) fish tend to be displaced from focal points by electrical currents and the activity of the workers; 2) certain habitat types or areas tend to be disproportionately sampled relative to other habitat types or areas; and 3) the efficiency of capture changes with different habitat types. In most cases, this strategy was probably successful in avoiding bias \#1. Most sampling was in clear and shallow (under $2 \mathrm{ft}$ deep) water, which allowed the crew to directly observe the fish and evaluate if they had been displaced. Bias \#2 was avoided in the sense that the entire length of both sampling sections was electrofished, and no areas were left out. However, there was some bias toward riffles, since these areas were investigated more thoroughly than pool areas. There were only two types of situations in which bias \#3 existed. In water depths up to about 3 feet deep it was possible to capture all stunned fish, but at greater depths some fish probably escaped detection or capture. Also, in areas with dense mats of aquatic vegetation, the capture efficiency went down because the stunned fish were concealed by the vegetation.

Habitat measurements were taken from one day to one month after electrofishing. In six areas where large numbers of fish were captured ("intensive-use areas"), thorough habitat mapping was conducted. A series of transects were established perpendicular to the streamflow, and typically spaced 5-10 ft apart. Upstream and downstream limits of the transects were designed to bracket the capture sites, so that at least one transect was located upstream and one downstream from the uppermost and lowermost capture sites, respectively. Between these limits, other transects passed through most capture sites. water depth and velocity were measured at $1.09 \mathrm{ft}(0.33 \mathrm{~m})$ intervals along each transect, although in a few backwater areas an interval of $3.28 \mathrm{ft}(1.0 \mathrm{~m})$ was used. Substrate and cover were determined by estimating the amount or percent in a cell, which was centered on the $1.09 \mathrm{ft}$ measurement sites and extended halfway to the adjacent measurement sites on the same transect and halfway to the neighboring transects both up and downstream (Figure 2). Water depth and mean velocity measurements (at $6 / 10$ ths depth) were taken with a Type AA flow meter (Teledyne and price models) and rod. Substrate composition was visually 


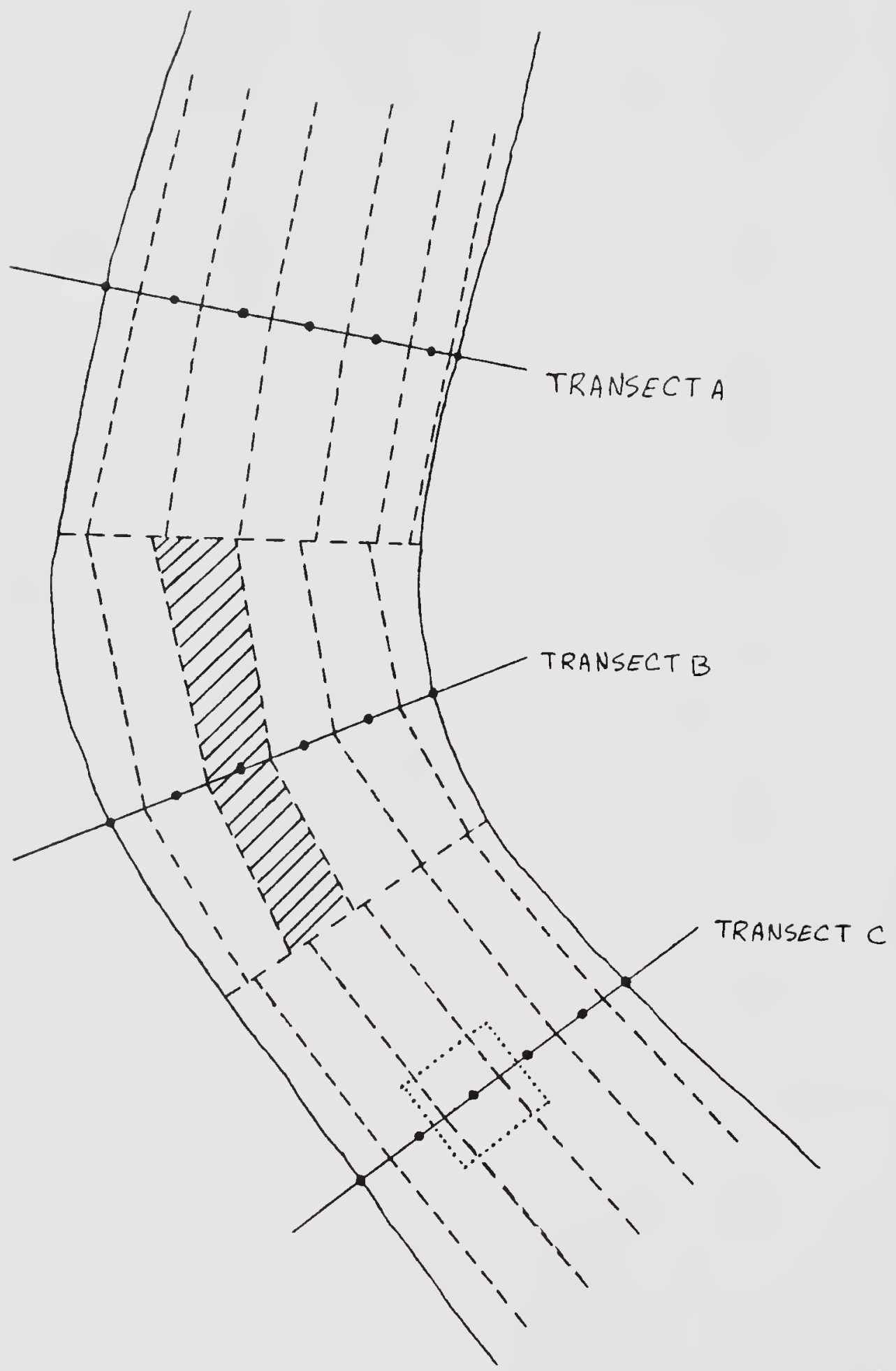

Figure 2. Example of the transect-grid system used to measure habitat variables. Dots along transects are at $1.09-\mathrm{ft}$ intervals and indicate locations where depth and velocity are measured. Dashed lines indicate boundaries of cells, within which cover, substrate and embeddedness are estimated. The shaded area represents one cell. The square cell (dotted lines) is a $3.28 \mathrm{ft}^{2}$ area used to measure all variables at the capture site. 
classified into size categories of silt ( $<0.00244$ in), sand (0.0024-0.0787 in), small gravel (0.0787-0.236 in), large gravel (0.236-2.52 in), cobble (2.52-9.84 in), and boulder (>9.84 in). Embeddedness was visually estimated by examining individual cobble or large gravel particles for the level of the rock stained by the substrate in which they were embedded. Percent embeddedness was determined by dividing the distance from the stain line to the bottom of the rock by the distance from the top to the bottom of the rock. Cover was visually estimated, and cover types were aquatic vegetation, terrestrial vegetation (no higher than 1 foot above water surface), submerged soil clumps (products of sloughing banks), undercut banks, rocks, and turbulence. Cover was only classified as such if it was deemed to be usable by the fish. Intensive habitat measurements were taken at each capture site, using a $3.28 \mathrm{ft}^{2}\left(1 \mathrm{~m}^{2}\right)$ cell centered on the capture site. Water depth and velocity (mean and bottom), substrate, embeddedness, cover, cover type and distance to nearest cover (including type of cover) were measured.

In areas where only a few age $0+$ fish were captured ("non-intensive-use areas"), habitat measurements took one of two forms: 1) measurements of water depth and velocity (mean and bottom), substrate, cover, cover type and distance to cover were determined for a $3.28 \mathrm{ft}^{2}$ area centered on the capture site; or 2) measurements were made along a single transect which ran through the capture site and was oriented perpendicular to the streamflow. Along this transect, measurements of depth and water velocity were taken at $1.09 \mathrm{ft}$ intervals, while estimates of substrate, cover and cover type were made at $3.28 \mathrm{ft}$ intervals along the transect. Intensive measurements at the capture sites were also taken in the $3.28 \mathrm{ft}^{2}$ cell as described above.

Water temperatures were measured with pocket thermometers throughout the duration of the study. Thermometers had $1^{\circ} \mathrm{F}$ markings, and temperatures were measured to the nearest $0.5^{\circ} \mathrm{F}$. Measurements were taken as time permitted, on an irregular basis, with most of the measurements being taken from mid-morning to early afternoon.

All data recorded for evaluation of habitat utilization were computerized for easier analysis using a Zenith 286 PC. Data were entered into DBASE IIIt software files modified for this study. Data files were sorted and loaded into statgraphics software files for analysis. Measurements of habitat features utilized by and available to YOY Arctic grayling were analyzed according to the recommendations of Bovee (1986). He suggested plotting frequency histograms of each habitat variable, and fitting a "utilization" or "availability" curve to the histograms. The curves are based on the principle of non-parametric tolerance limits, and are appropriate to use in situations where data sets are small and distribution is not 
expected to be normal. Curves are developed by assigning normalized weighting factors of $1.0,0.5$ and 0.2 to the range of the variable that encompasses $50 \%, 75 \%$ and $90 \%$, respectively, of the observations. In this study, curves were developed at the 95\% confidence level.

The streamflow discharge and water levels of Swamp creek and the east channel of the Big Hole River below the wisdom bridge were monitored on a regular basis. On Swamp creek, water-level measurements were taken from August 16 to september 8, by making reference to the top of a stake placed in the stream at the upper end of the sample section. One discharge measurement station was established about midway through the sample section, and measurements were taken from August 17 to september 8 . On the Big Hole River, three discharge measurement stations were established. All stations were located in the middle third of the sample section, and measurements were taken from August 4 to september 7 . Water levels were measured by making reference to the top of a stake placed in the stream about midway through the sample section; measurements were taken from August 3 to september 7 . 


\section{RESULTS AND DISCUSSION}

\section{Distribution and abundance of fishes}

Age 0+ Arctic grayling were found in highest concentrations in Swamp Creek, the west channel of the Big Hole River above and below the bridge (including an associated irrigation ditch), and the east channel below the bridge (sample sections D,E,G,H,J and $L)$, while only one age $0+\mathrm{fish}$ was found in the upper sample sections (A,B,C and I) (Table 2). Older Arctic grayling followed this same pattern of occurrence, with three notable differences: 1) seven age I+ grayling (6-9 inches) were found in Governor Creek; 2) no older grayling were found in Swamp Creek; and 3) no older grayling were found in the irrigation ditches.

Several investigators have found Arctic grayling in other areas of the upper Big Hole River drainage in recent years. Liknes (1981), in his extensive survey of the upper drainage in 1978 and 1979, found age 0+ grayling ranging from Governor Creek downstream to an area near the mouth of Fishtrap creek. Young-of-the-year fish were also found in an irrigation ditch off the North Fork of the Big Hole River. Distribution of age I and older fish in the main stem was restricted to the area between Tom Clemow Lane and the wisdom cemetery, but they were also found in numerous tributaries, including the inlet and outlet of lakes on Miner and Mussigbrod Creeks, respectively. In surveys conducted since 1986, MDFWP personnel have found age $I$ and older grayling in numerous other tributaries to the Big Hole River, including Fishtrap, LaMarche and Deep creeks and the wise River (Brad Shepard, pers. comm.). The fish in the wise River were in the mainstem and Wyman and O'Dell creeks, and likely drifted downstream from lakes in the drainages.

Young-of-the-year brook trout (Salvelinus fontinalis) were plentiful in two of the upper sample sections (B and $C$ ), the tributaries (sample sections $I, J$ and $K$ ) and the east channel of the Big Hole River below the bridge (sample section $H$ ). They were scarce in all other sample sections around the wisdom Bridge ( $D, E, F$ and $G$ ) and absent in the irrigation ditches. Older brook trout followed this same general pattern, except that older fish were plentiful in sample section A.

Rainbow trout (oncorhynchus mykiss) were plentiful only in the Dooling Bridge sample section (A) and in Governor creek (sample section I). Only nine rainbow trout were found in lower sample sections of the drainage, and may have drifted down from upper portions of the drainage.

Certain patterns of distribution were apparent for other fishes captured in the study Area (Table 3). The occurrence of mountain whitefish (Prosopium williamsoni) was quite variable, and there were only three sample sections ( $B, C$ and $G$ ) where 
Table 2. Total number and relative abundance of Arctic grayling and trout captured by electrofishing in the Big Hole River drainage, July 6 - September 1, 1988.

\begin{tabular}{|c|c|c|c|c|c|c|c|c|c|}
\hline \multirow[b]{2}{*}{$\begin{array}{l}\text { Stream/ } \\
\text { Sample Section' }\end{array}$} & \multicolumn{3}{|c|}{$\begin{array}{l}\text { Number of fish ce } \\
\text { Arctic grayling }\end{array}$} & \multicolumn{3}{|c|}{ brook trout } & \multicolumn{3}{|c|}{ rainbow trout } \\
\hline & Yor & $<9$ in & $>9$ in & yor & $<6$ in & $>6 \mathrm{in}$ & Yor & $<6$ in & $>6$ in \\
\hline \multicolumn{10}{|l|}{ Big Hole River } \\
\hline A - Dooling Bridge & $0(0)$ & $0(0)$ & $0(0)$ & $0(0)$ & $15(19)^{3}$ & $30(37)^{3}$ & $0(0)$ & $39(3.8)$ & $27(2.6)$ \\
\hline B - Nelson Lane & $0(0)$ & $1(0.3)$ & $1(0.3)$ & $150(53)^{4}$ & $3(0.8)$ & $105(30)$ & $0(0)$ & $0(0)$ & $2(0.6)$ \\
\hline C - Hirschy Ranch & $0(0)$ & $2(0.3)$ & $0(0)$ & $106(14)$ & $1(0.1)$ & $153(20)$ & $0(0)$ & $0(0)$ & $2(0.3)$ \\
\hline $\begin{array}{l}\text { D- Above Wisdom Br. } \\
\text { (upper west channel) }\end{array}$ & $9(0.5)$ & $5(0.3)$ & $4(0.2)$ & $1(0.1)$ & $1(0.1)$ & $38(2.2)$ & $0(0)$ & $0(0)$ & $1(0.1)$ \\
\hline $\begin{array}{l}\text { E - Above Wisdon Br. } \\
\text { (lower west channel) }\end{array}$ & $42(3.1)$ & $19(1.4)$ & $6(0.4)$ & $1(0.1)$ & $0(0)$ & $17(1.2)$ & $0(0)$ & $0(0)$ & $2(0.1)$ \\
\hline $\begin{array}{l}\text { F- Above Wisdom Br. } \\
\text { (east channel) }\end{array}$ & $1(0.1)$ & $0(0)$ & $0(0)$ & $0(0)$ & $0(0)$ & $6(0.6)$ & $0(0)$ & $0(0)$ & $0(0)$ \\
\hline $\begin{array}{l}\text { G- Below Hisdom Br. } \\
\text { (west channel) }\end{array}$ & $50(2.7)$ & $2(0.1)$ & $1(0.1)$ & $1(0.1)$ & $1(0.1)$ & $21(1.1)$ & $0(0)$ & $0(0)$ & $0(0)$ \\
\hline $\begin{array}{l}\text { H - Below Wisdom Br. } \\
\text { (east channel) }\end{array}$ & $196(13)$ & $14(0.9)$ & $10(0.7)$ & $162(11)$ & $18(1.2)$ & $44(2.9)$ & $0(0)$ & $0(0)$ & $2(0.1)$ \\
\hline \multicolumn{10}{|l|}{ Tributaries } \\
\hline 1 - Governor Creek & $1(0.2)$ & $7(1.7)$ & $0(0)$ & $33(9.8) 5$ & $46(14)^{5}$ & $204(61)^{5}$ & $0(0)$ & $1(0.2)$ & $21(5.0)$ \\
\hline J. Swamp Creek & $51(5.0)$ & $0(0)$ & $0(0)$ & $299(29)$ & $1(0.1)$ & $89(8.8)$ & $0(0)$ & $0(0)$ & $0(0)$ \\
\hline K - steel Creek & $3(0.4)$ & $4(0.5)$ & $2(0.3)$ & 177 (24) & $129(18)$ & $78(11)$ & $0(0)$ & $0(0)$ & $0(0)$ \\
\hline
\end{tabular}

Irrigation ditches

\begin{tabular}{|c|c|c|c|c|c|c|c|c|c|c|}
\hline & $\begin{array}{l}\text { Above Wisdom Br. } \\
\text { (McDowell Ranch) }\end{array}$ & $65(8.6)$ & $0(0)$ & $0(0)$ & $0(0)$ & $0(0)$ & $5(0.7)$ & $0(0)$ & $0(0)$ & $0(0)$ \\
\hline M - & $\begin{array}{l}\text { Above Wisdom Br. } \\
\text { (McDowell Ranch) }\end{array}$ & $4(1.0)$ & $0(0)$ & $0(0)$ & $0(0)$ & $0(0)$ & $0(0)$ & $0(0)$ & $0(0)$ & $0(0)$ \\
\hline N. & $\begin{array}{l}\text { Above Wisdom Br. } \\
\text { (near airport) }\end{array}$ & $0(0)$ & $0(0)$ & $0(0)$ & $0(0)$ & $0(0)$ & $0(0)$ & $0(0)$ & $0(0)$ & $0(0)$ \\
\hline
\end{tabular}

'These sample sections correspond to sampling sections used in figure 1.

${ }^{2}$ YOY $=$ young-of-the-year $f$ ish; $<6,>6,<9,>9=f i$ sh under and over 6 and 9 inches, respectively. Fish $<9$ inches are assumed to be age $1+f i s h$, and $f i s h>9$ inches are age $11+$ and older fish.

${ }^{3}$ Numbers are only for the first $806 \mathrm{ft}$ sub-section; numbers were not recorded for the remaining sub-section, but were termed "abundant."

"Does not include the last $684 \mathrm{ft}$ sub-section.

${ }^{5}$ Does not include a $827 \mathrm{ft}$ sub-section. 
Table 3. Relative abundance of mountain whitefish, burbot and non-game fish in the Study Area.

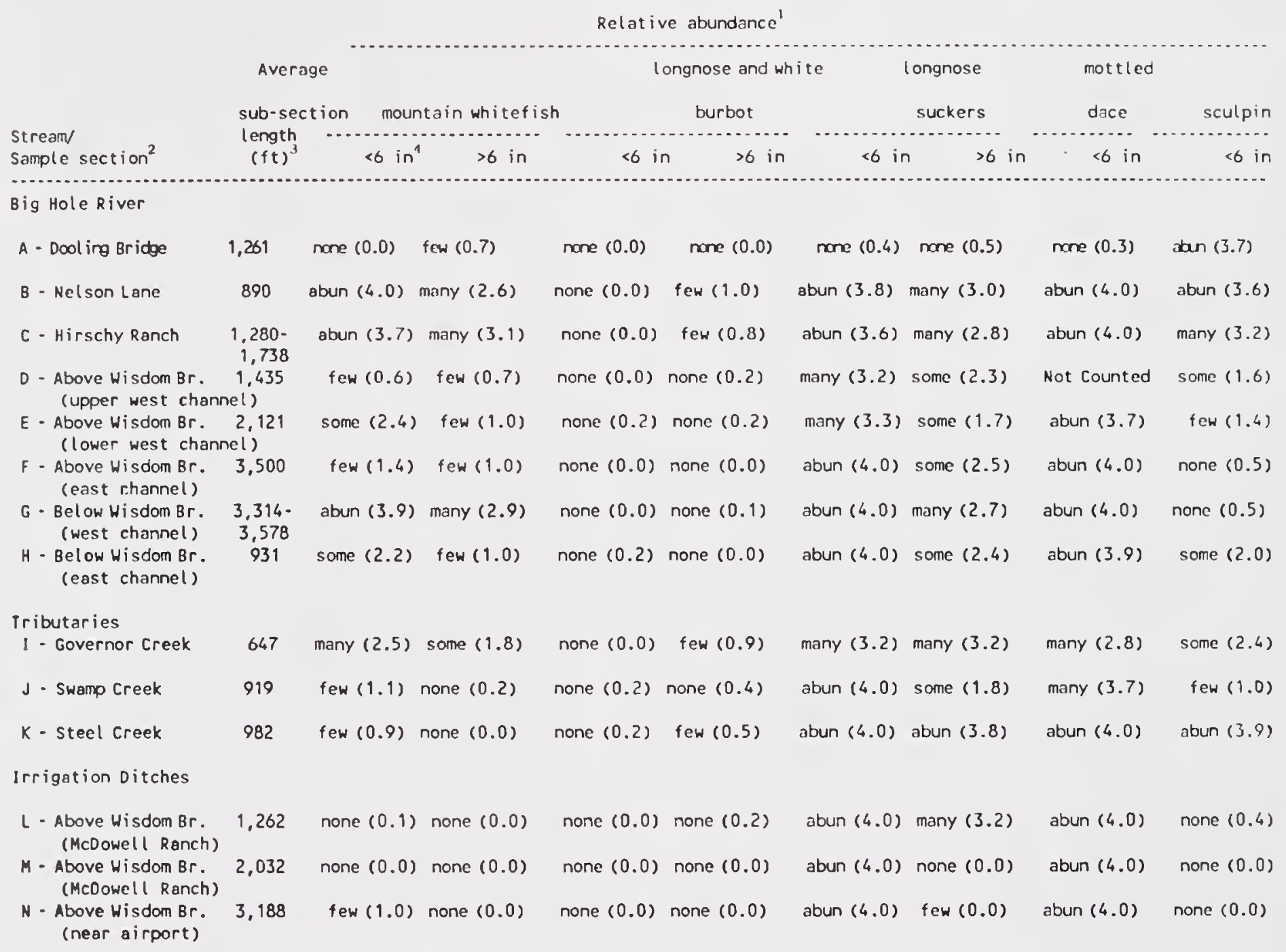

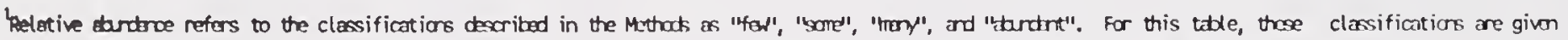

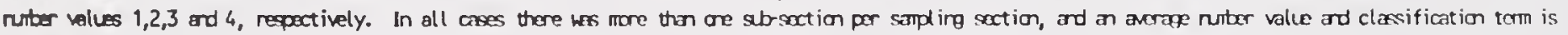
therefore presented. Because ab-section lengths were uncalal, the individal rumber valurs were adjusted by a weighting factor, which wis the legth of the

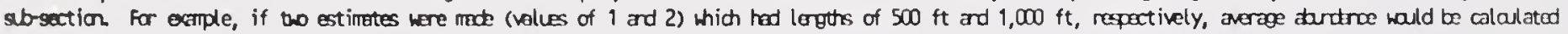
by: $(1)(500)+(2)(1,000) / 1,500=1.67$.

${ }^{2}$ These sample sections correspond to sample sections used in figure 1.

3 Average sub-section lengths varied in some cases because certain species were not counted in some sub-sections.

$>6, \quad 66=f$ ish over and under 6 inches, respectively. 
numbers of both small and large whitefish were consistently high throughout the sample section. Whitefish were notably scarce in the irrigation ditches and Swamp and steel creeks. Burbot (Lota lota) were scarce througout the study Area, and never received a rating higher than "few." Burbot over 6 inches were encountered much more often than individuals under 6 inches, but the larger fish were found consistently only in sample sections $B, C$ and $I$. suckers were found in high numbers throughout the study Area, with the exception of sample section $A$, where they were absent. sucker fry were particularly abundant, with the number of individuals per sub-section often exceeding 100. No attempt was made to separate the abundance of longnose suckers (Catostomus platyrhynchus) from white suckers (Catostomus commersoni), although longnose suckers were generally in far greater abundance. Longnose dace (Rhinichthys cataractae) were found in high numbers throughout the study Area, except in sample section A, which has the highest gradient and largest substrate of any sample section. Mottled sculpin (Cottus bairdi) were most plentiful in the upper sample sections (A,B and C) and steel Creek, and almost absent from irrigation ditches.

\section{Growth of Arctic grayling}

Between July 7 and september 1, the mean total length ( \pm SD) of YOY Arctic grayling increased from $2.45 \pm 0.12$ inches to 4.26 \pm 0.37 inches (Table 4, Figure 3). These fish are considerably longer than those measured by Liknes (1981) for the same time of year. He sampled 44 age $0+$ grayling in Sandhollow creek and the North Fork of the Big Hole from July 11-15, 1979 and found a mean total length ( $\pm S D$ ) of $2.17 \pm 0.22$. During the same general time period in 1988 (July 12- 14), 24 age 0+ grayling from the Big Hole River immediately upstream from the Wisdom Bridge had a mean total length $( \pm S D)$ of $2.68 \pm 0.19$ inches. This size difference could be due to temperature differences between these two tributaries and the mainstem of the Big Hole River, although this cannot be substantiated because tributary water temperatures were not measured. Spawning periods during the two years were similar, and probably cannot contribute to an explanation of the size difference. Liknes reported that most spawning in the Big Hole River in 1979 occurred from late April to early May. Shepard (1989) believed spawning occurred from the end of April through the first week in May in 1988, based on observations of the first ripe fish on April 20 and the first spent fish on May 4 .

The length-frequency distribution of Arctic grayling over 6 inches had two peaks, apparently corresponding to age It and IIt fish (Figure 4). Fish assigned to age It were mainly between 7.0-8.5 inches, age IIt fish were mainly between $9.0-11.0$ inches, and the two fish over 11.0 inches may have been age IIIt fish 
Table 4. Mean and range of total length (in) of age 0 + Arctic grayling and brook trout in the $B$ ig Hole River, July 7 - September 1, 1988.

\begin{tabular}{|c|c|c|c|c|c|c|c|}
\hline \multirow[b]{2}{*}{ Date } & \multicolumn{4}{|c|}{ Arctic grayling } & \multicolumn{3}{|c|}{ brook trout } \\
\hline & $\begin{array}{l}\text { Location } \\
\text { (Reaches) }\end{array}$ & $\begin{array}{l}\text { Mean }( \pm S D) \\
\text { (in) }\end{array}$ & $\begin{array}{l}\text { Range } \\
\text { (in) }\end{array}$ & N & $\begin{array}{l}\text { Mean }( \pm S D) \\
(\text { in })\end{array}$ & $\begin{array}{l}\text { Range } \\
\text { (in) }\end{array}$ & N \\
\hline Jul $7 \cdot 8$ & $D, L, M$ & $2.45(0.12)$ & $2.2 \cdot 2.6$ & 16 & -- & $-\cdot$ & $\cdots$ \\
\hline Jul 12-14 & $E, F, G$ & $2.68(0.19)$ & $2.3-3.0$ & 24 & $\cdots$ & $\cdots$ & $-\cdot$ \\
\hline Jul $20-21^{1}$ & $H, K$ & $2.97(0.11)$ & $2.8-3.2$ & 18 & $2.64(0.25)$ & $2.0-3.3$ & 33 \\
\hline Aug 3-4 & H & $3.33(0.23)$ & $2.8 \cdot 3.8$ & 107 & $2.96(0.29)$ & $2.6-3.4$ & 5 \\
\hline Aug $9-10$ & H & $3.66(0.23)$ & $3.1-4.1$ & 73 & $3.27(0.31)$ & $2.5-3.8$ & 98 \\
\hline Aug $16-17$ & $\mathrm{~J}$ & $4.01(0.30)$ & $3.5-4.7$ & 50 & $3.64(0.42)$ & $2.6-5.0$ & 288 \\
\hline Aug 30-Sept 1 & $H, J$ & $4.26(0.37)$ & $3.6-5.3$ & 33 & $-\cdot$ & $\cdots$ & $\cdots$ \\
\hline
\end{tabular}

'Brook trout were sampled only in sample section $H$ on July 21. 


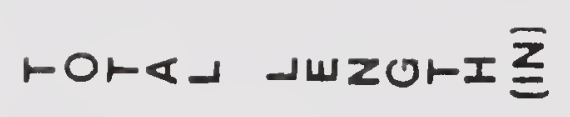
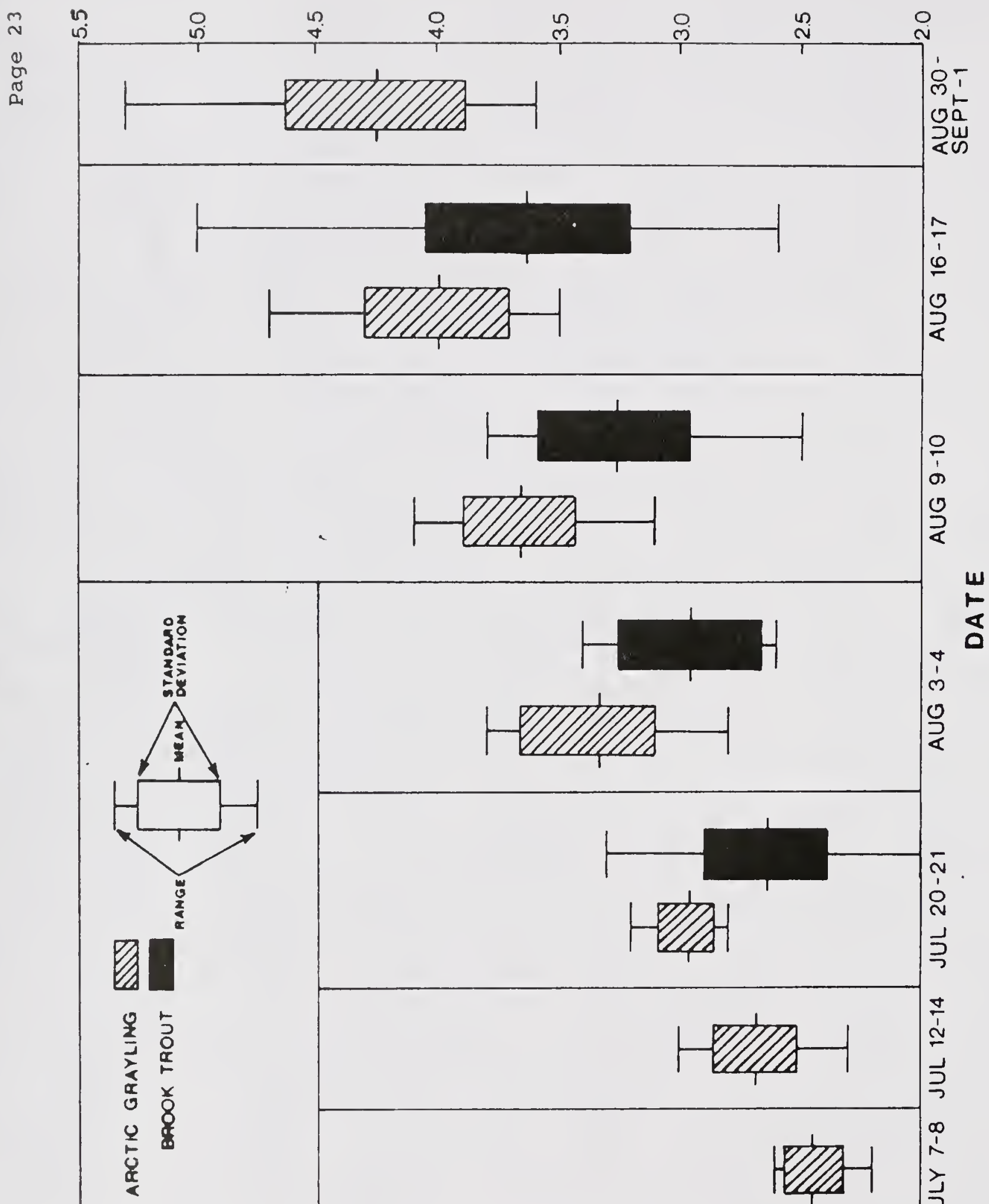

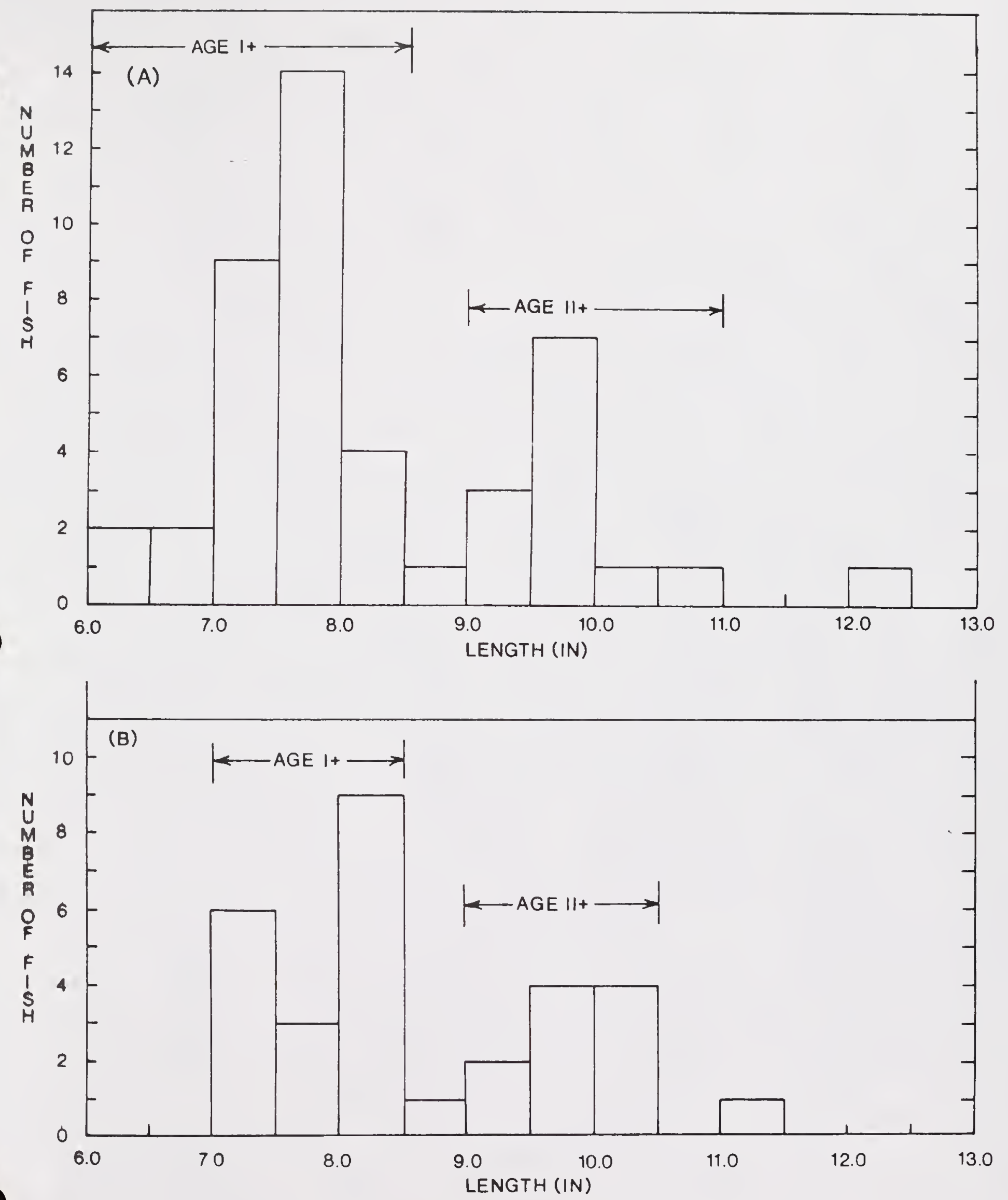

Figure 4. Length-frequency distribution of age It and older Arctic grayling in the upper Big Hole River drainage in July (A) and August (B) 1988. Assignment of age $\mathrm{classes} 1+$ and $11+$ to the peaks in frequency is based on age-growth information in Liknes (1981). 
(assignment of lengths to age groups was based on body

length-scale radius relationships derived by Liknes [1981]). The relative abundance of the fish in the different size/age groups was in stark contrast to that found by Liknes (1981) in two sections in the Wisdom area in August 1978. The percentage of fish in each of the size groups of 6.0-9.0,9.0-11.0 and $11.0+$ inches was $18.3,55.6$, and 26.1 , respectively. Comparable percentages for $\mathrm{fish}$ found in the wisdom area in 1988 (a subset of data presented in Figure 4) were $65.6,32.8$ and 1.6 , apparently showing that age It fish were relatively much more abundant in 1988 than in 1978, and age II+ and older fish were relatively much less abundant. However, the ratios in 1988 may be to some degree an artifact of the sampling techniques, which were very inefficient at sampling many of the large pools that were felt to be good habitat for large grayling. Furthermore, the relative strength of the year classes could have been different in 1978 than in 1988.

Condition factors (K) were calculated for age I+ and older fish and compared to a similar analysis by Liknes (1981), who collected fish in July and August from a section below the Wisdom bridge. For fish between 6.9 and 22.4 inches, he calculated a mean $K$ value ( $\pm S D$ ) of $0.95 \pm 0.08$. In this study, mean $K$ values ( \pm SD) for all age $I+$ and older fish in the study area were 1.06 \pm 0.11 . The relatively good condition of the fish in this study was not expected. The high water temperatures and reduced space caused by reduced discharge were anticipated to be stressful factors that might contribute to poor condition.

\section{Habitat Utilization by Young-of-the-Year Arctic grayling}

\section{Macrohabitat utilization}

Swamp creek (sample section $J$ ) and the east channel of the Big Hole River below the Wisdom bridge (sample scction $H$ ) were characterized for habitat use because they contained high densities of YOY Arctic grayling ( 5 and $13 \mathrm{fish}$ per $1000 \mathrm{ft}$, respectively). Some macrohabitat features of the two sample sections were very similar, including discharge, gradient, sinuosity, bank height and condition, and channel shape (Table 5). Channel width and wetted stream width were somewhat greater for the Big Hole River $(72.3 \mathrm{ft}$ and $18.0 \mathrm{ft}$, respectively) than for Swamp Creek (60.2 ft and $14.8 \mathrm{ft}$, respectively). Arctic grayling in both areas seemed to be orienting to the riffles. For the Big Hole River and Swamp Creek, the YOY fish were captured $23.9 \mathrm{ft}$ and $27.2 \mathrm{ft}$, respectively, downstream from the base of riffles and were in faster water--rapids, low-gradient riffles or runs--at $84.4 \%$ and $74.1 \%$ of the capture sites, respectively. 
Table 5. Macrohabitat features of Swamp Creek and the east channel of the Big Hole River below the Wisdom Bridge. Standard deviations, where applicable, are in parenthesis.

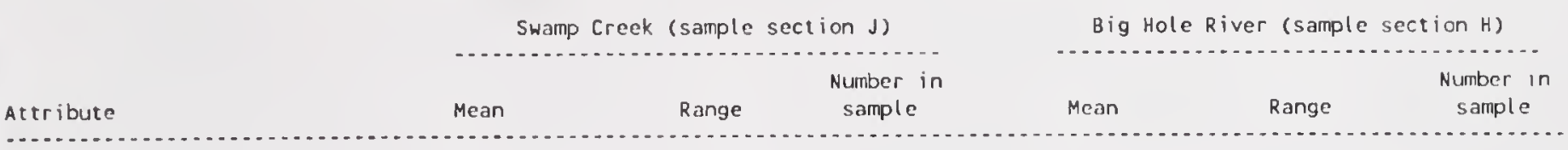

General characteristics of entire sample section

$\begin{array}{lccccc}\text { Length (miles) } & 1.92 & \text { N/A } & \text { N/A } & 2.83 & \text { N/A } \\ \text { Discharge }\left(\mathrm{ft}^{3} / \mathrm{s}\right) & \text { N/A } & 1.1-3.9 & \text { N/A } & \text { N/A } & \text { N/A } \\ \text { Gradient }(\%) & 0.28 & \text { N/A } & \text { N/A } & 0.27 & \text { N/A } \\ \text { Sinuosity } & 1.33 & \text { N/A } & \text { N/A } & 1.27 & \text { N/A }\end{array}$

Channel shape

Bank condition and vegetation

Bank height $(f t)$

Hetted stream width $(f t)$

Channel width $(f t)$

Habitat type at capture site

( $x$ of each type):

Rapid
Low-gradient riffle
Run
Slow Run
Pool

-.

18.5

55.6

7.4

18.5
Meanders in a single channel. New channel formation has occurred in one area at the is thmus of a meander loop.

Grasses \& sedges predominate throughout the section. Shrubs are sparse throughout but are densest near upper end. Banks along outside bends typically sloughing. Cattle grazing heavy in middle portions of section.
Primarily meanders in a single channel. although double channel areas occur frequently, typically resulting from sediment deposition or meander loop cutoffs.

\section{Characteristics relating to the capture sites}

$\begin{array}{llllll}2.50(0.30) & 2.0-2.9 & 10 & 2.51(0.57) & 0.5 \cdot 3.6 & 67 \\ 14.77(1.85) & 11.6-16.4 & 5 & 18.04(8.78) & 8.2 \cdot 43.2 & 34 \\ 60.19(1.76) & 57.1-61.1 & 5 & 72.28(29.30) & 38.7 \cdot 122.0 & 32\end{array}$

Distance from capture site:

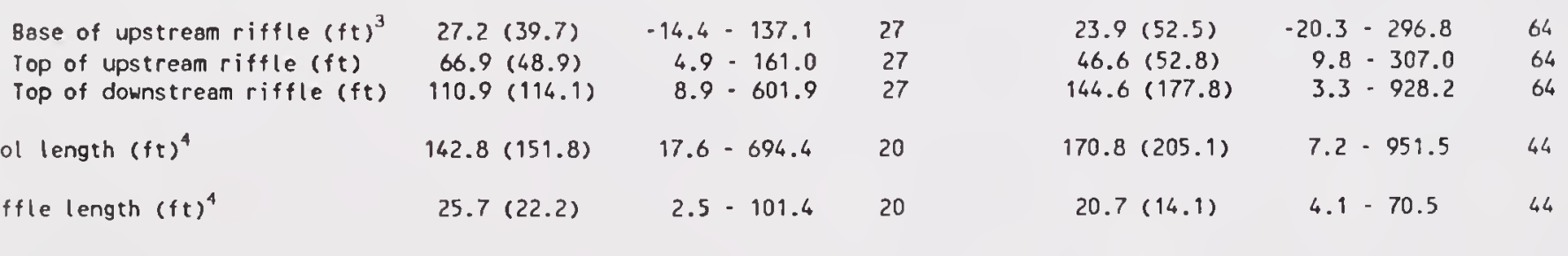

'Sinuosity = distance measured along midpoint of channel/downvalley length of channel $\times 100$.

${ }^{2}$ Criteria for habitat types are as follows: rapid -. a steep, shallow area where the water surface is rough and broken by whitewater: low-gradient riffle -- shallow area where water surface is rough, but not broken by whitewater; run -- deeper then a riffle, with an obvious current, and a water surface that is not as rough as a riffle; slow run .. slow version of a run; pool --as deep or deeper than a run with a smooth water surface and a current that is detectable only upon close inspection.

${ }^{3}$ Negative distances indicate that the fish was in the riffle.

"For these calculations, "riffle" is includes those areas defined as "riffle" or "rapid" in footnote "2" above, thile "pool" includes all other areas. Size of pools and riffles was determined by using distances from capture sites to upstream and downstream riffles. 


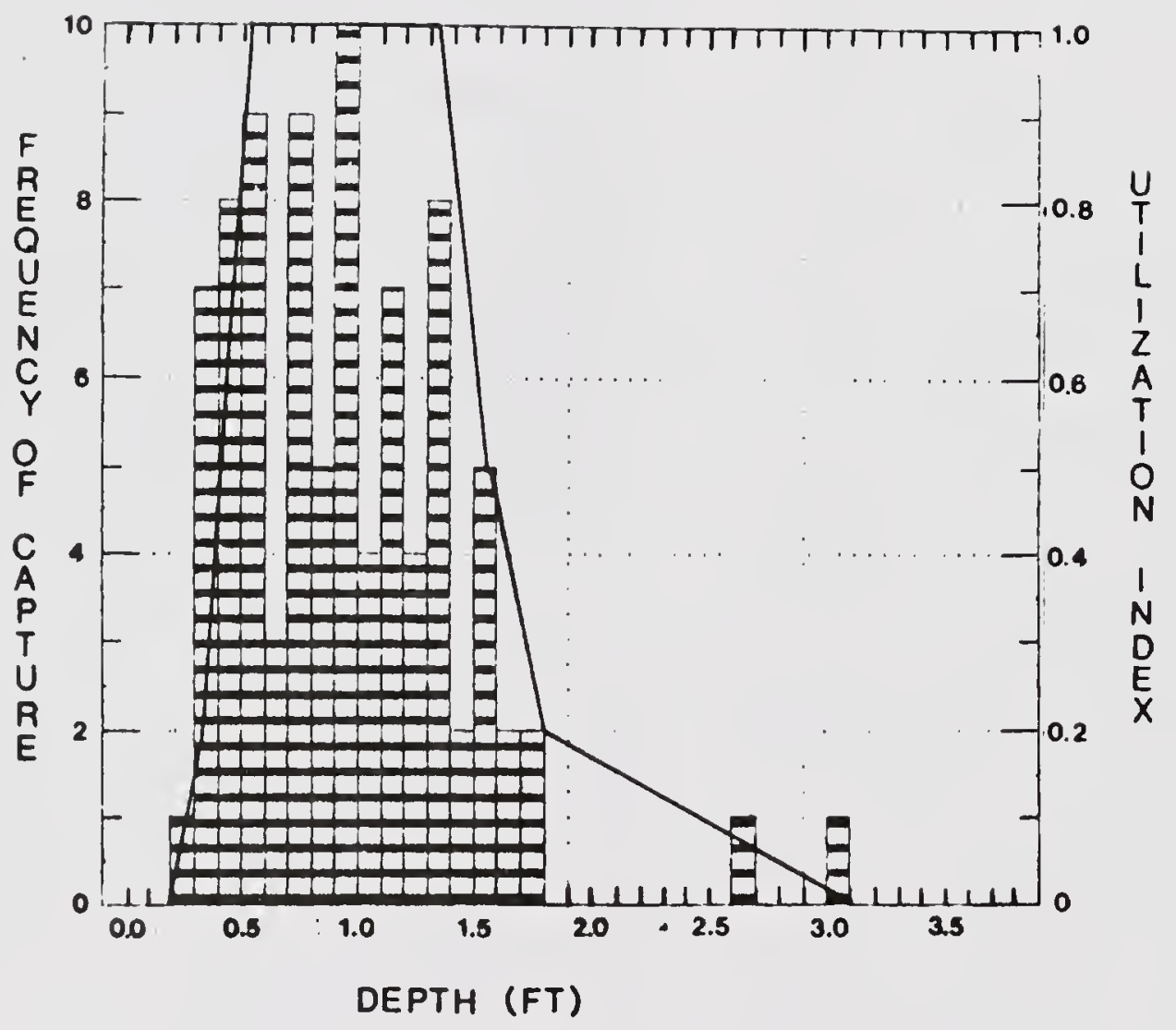

Figure 5. Frequency of depth measurements at capture sites of young-of-the year Arctic grayling. 


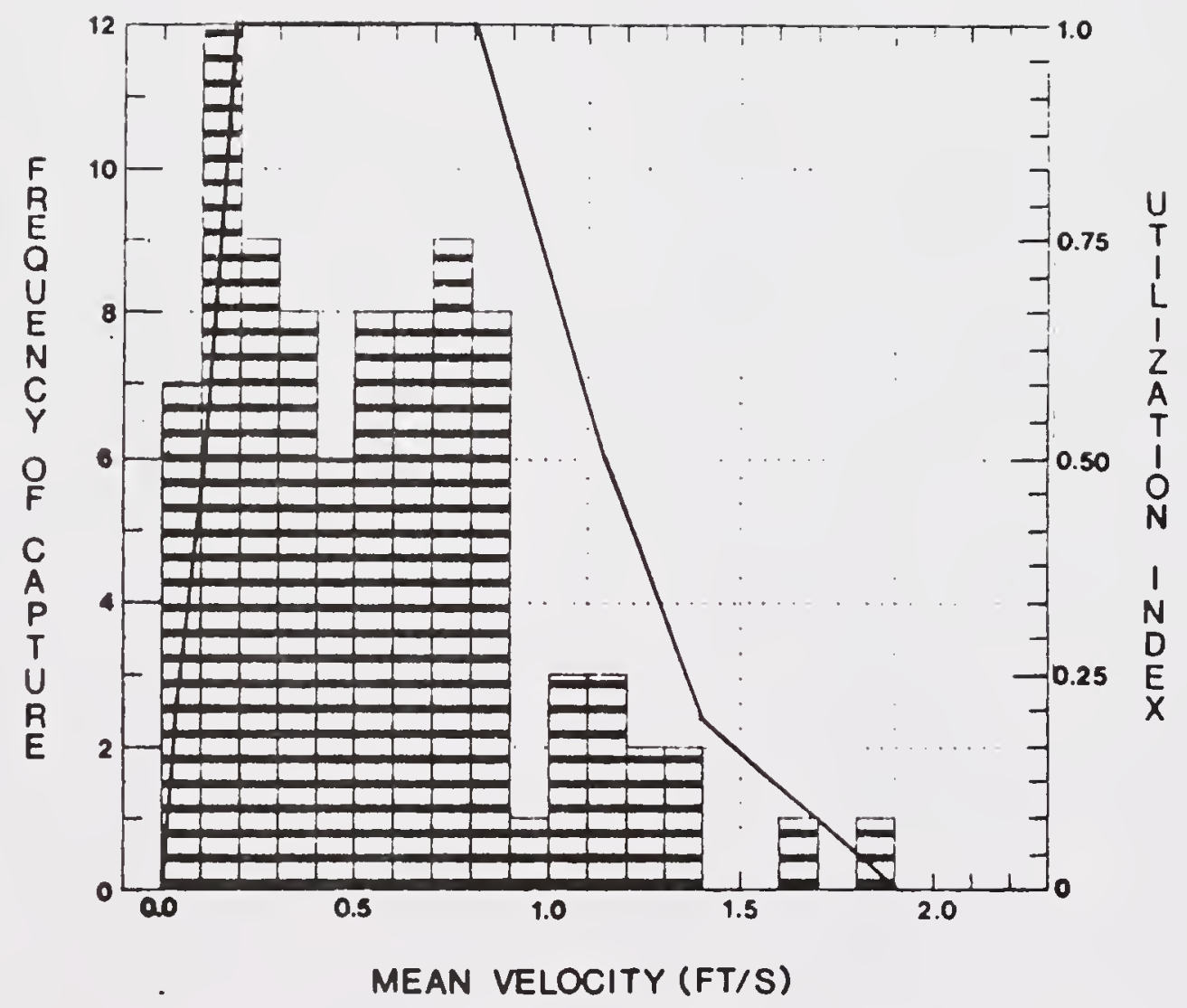

Figure 6. Frequency of mean velocities measurements at capture sites of young-of-the-year Arctic grayling. 


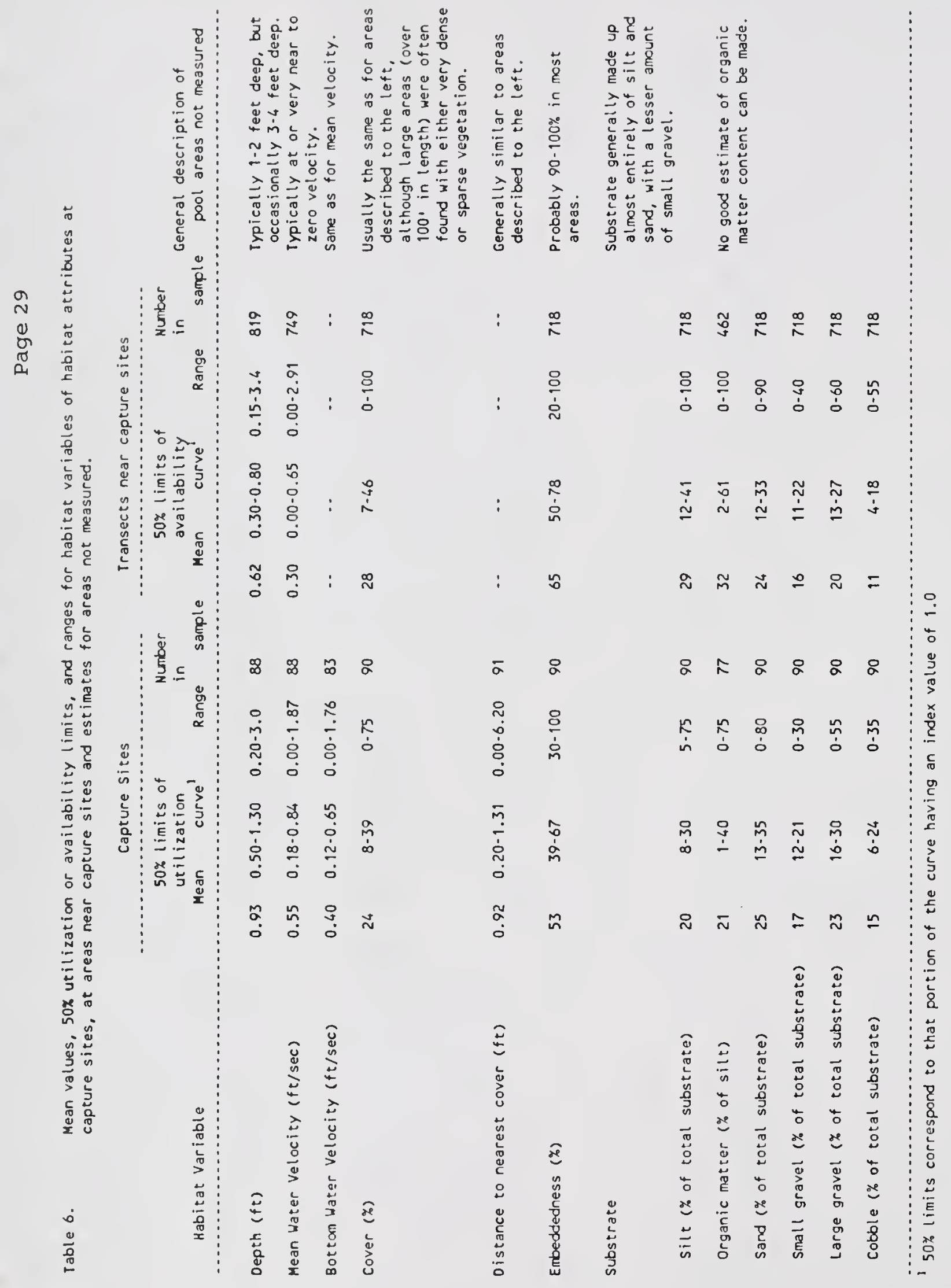




\section{Microhabitat Utilization}

\section{Depth and Velocity}

Young-of-the-year Arctic grayling were captured at depths ranging from 0.2 to $3.0 \mathrm{ft}$ in water with velocities ranging from 0.0 to $1.87 \mathrm{ft} / \mathrm{s}$ (Figures 5 and 6 , Table 6). Depths and velocities falling within the range of the utilization index value of 1.0 were 0.5 to $1.3 \mathrm{ft}$ and 0.18 to $0.84 \mathrm{ft} / \mathrm{s}$, respectively. These ranges may not accurately reflect the preferences of the fish, because the preferred depths and velocities may not be present or may be in short supply. Preference is typically thought to be exhibited when a particular habitat variable is utilized with a frequency that is greater than its relative availability (Bovee 1986). An unbiased determination of habitat availability is possible only if a sampling approach is used that provides for variables to be measured in all habitat types (pools, riffles, backwater areas, side channels, etc.) throughout the entire study Area and in proportion to the frequency of occurrence of those habitat types. This sampling approach was not employed in this study and accurate determinations of preference are therefore not possible. However, habitat variables were measured along 50 transects that went through or near to capture sites, and frequency analysis of these data were used to provide a rough idea of the availability of depths and velocities in areas close to the capture sites. Results show that depths and velocities within the 1.0 index range were 0.3 to $0.8 \mathrm{ft}$ and 0.0 to $0.65 \mathrm{ft} / \mathrm{s}$, respectively (Figures 7 and 8 , Table 6). Compared to the utilization data, this is somewhat slower and shallower water, and suggests that, within the areas close to capture sites, the fish are preferentially selecting for the faster and deeper areas.

A significant limitation in the availability database is that, for the most part, it does not include pool habitats, because few YOY fish were found in or near these habitat types. If estimates of conditions in the pools (righthand column in Table 6) are also considered, there will probably be a relative increase in the amount of deeper water available to the fish (water is mostly from 1-4t ft deep) and a relative decrease in the amount of available fast water (most water in pools has little or no current). This tends to support the hypothesis that the fish are selecting for faster water, but would suggest that deeper water is not being selected preferentially. one possible explanation for why the fish seem to be selecting for deeper water in the areas near capture sites, but not in the pools, could be the threat of predation by large brook trout in the pools. If the YOY Arctic grayling are avoiding the pools for this reason, then this habitat type may not truly be "available" in the sense that the fish are not free to select those areas, unencumbered by predation. Another possible explanation could be that the fish are avoiding the pools because there is 


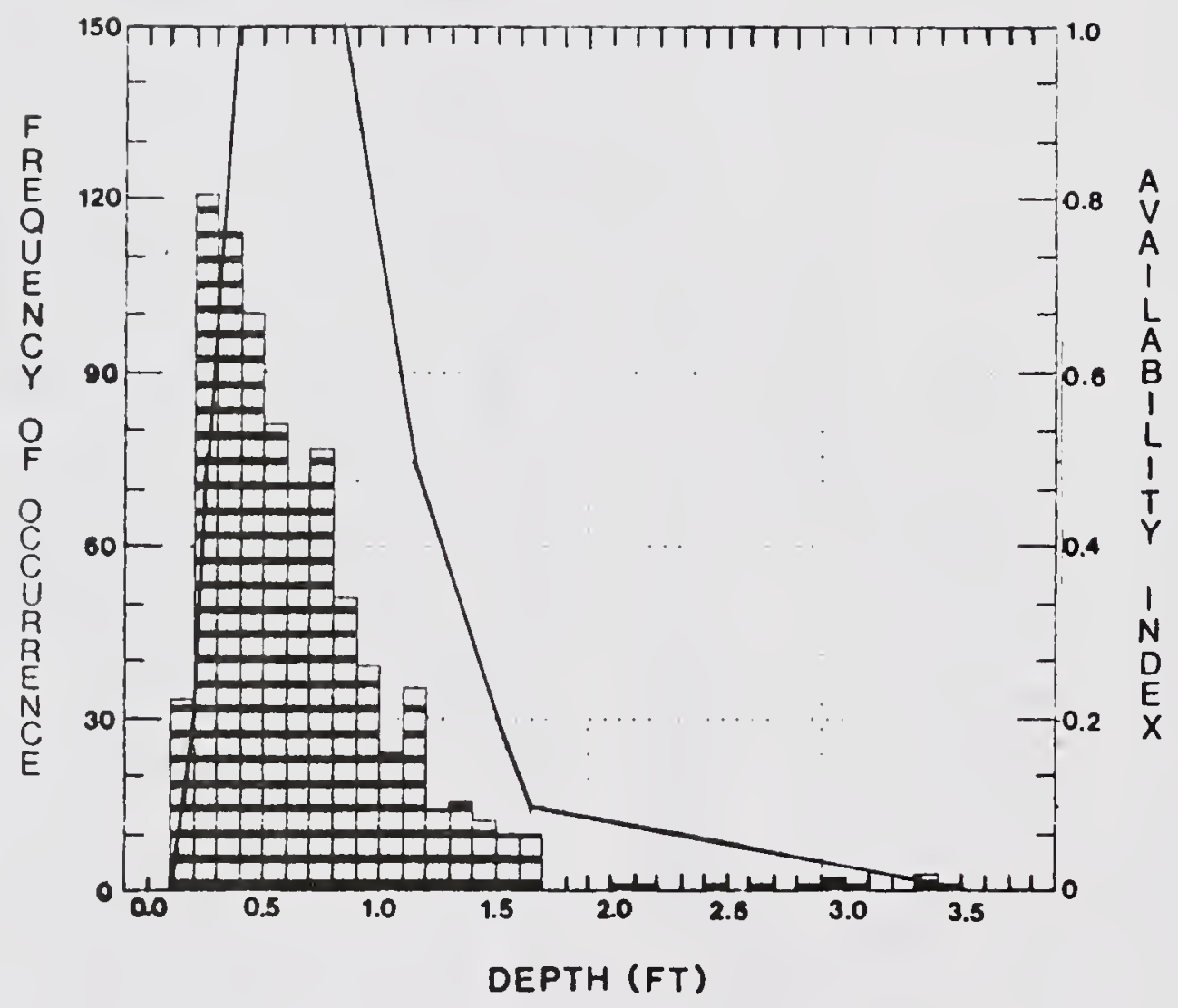

Figure 7. Frequency of depth measurements over $0.1 \mathrm{ft}$ in areas near young-of-the-ycar Arctic grayling capture sites. 


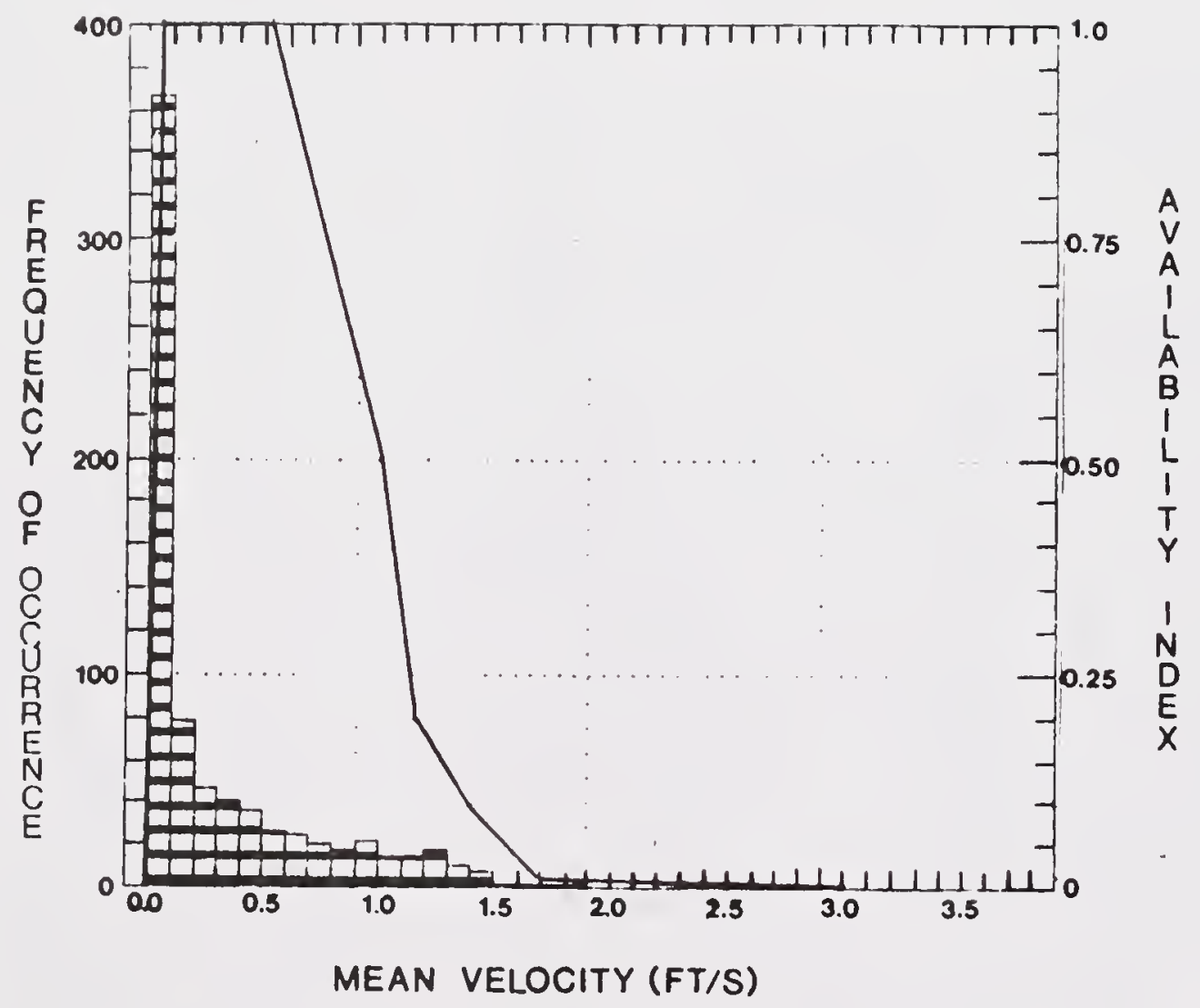

Figure 8. Frequency of mean velocity measurements in areas near young-of-the year Arctic grayling capture sites in water over $0.1 \mathrm{ft}$ deep. 
insufficient current. This argument is supported by the preference that has apparently been shown for flowing water--85 of 88 capture sites were in areas where there was a measurable current.

Fish may have been selecting habitat on the basis of an interaction between depth and velocity. Correlation analysis between the two variables in the utilization and availability databases was used to determine if such a relationship existed. Both databases were modified for the analysis by using the range of depth and velocity measurements found to be utilized by $95 \%$ of the fish (the highest $2.5 \%$ and the lowest $2.5 \%$ depth and velocity measurements were eliminated); in this way, measurements that were atypical of grayling fry usage were eliminated. The ranges for depth and velocity used in the analyses were therefore 0.30 to $1.70 \mathrm{ft}$ and 0.02 to $1.33 \mathrm{ft} / \mathrm{s}$, respectively. In the utilization database, a significant negative correlation existed between the two variables $(r=-0.53, P=<0.01$, d.f. $=80)$, with velocity increasing as depth decreased. A similar negative correlation existed between depth and velocity in the availability database ( $r=-0.24, P=<0.01, d . f .=373$ ). Because both databases show similar negative correlations, it seems likely that the phenomenon is due to physical properties of the stream (i.e., the way depth and velocity are affected by gradient, discharge and channel shape), and not due to active selection by fish. This is consistent with the observation that low-flows (under $4 \mathrm{cfs}$ ) on both streams resulted in conditions where high velocity water existed only in shallow riffles or rapids. This does not rule out the possibility that yoy grayling select habitat on the basis of an interraction of the two variables, but it suggests that a proper test for such a relationship would have to be conducted in these streams with greater discharge or in a different stream where similar correlations do not exist in both databases.

Isopleth contour maps of water depth and mean velocity were made for one intensive-use area on swamp creek and three such areas on the Big Hole River, (Figures 9 through 16; the locations of the intensive- use areas are shown in Figure 23). Proceeding on the assumption that water depth and velocity are chosen independently, the amount of "usable" area in the intensive-use areas was determined by delimiting those portions of the stream that encompassed the water depths and mean velocities found to be utilized by $95 \%$ of the YOY grayling $(0.30$ to $1.70 \mathrm{ft}$ for depth and 0.02 to $1.33 \mathrm{ft} / \mathrm{s}$ for velocity). The area determined in this way to be usable was primarily described as runs and portions of riffles (Figures 17 through 20). Usable habitat was also predominantly mid-stream, with very few cases where appropriate depth-velocity combinations were against banks. 


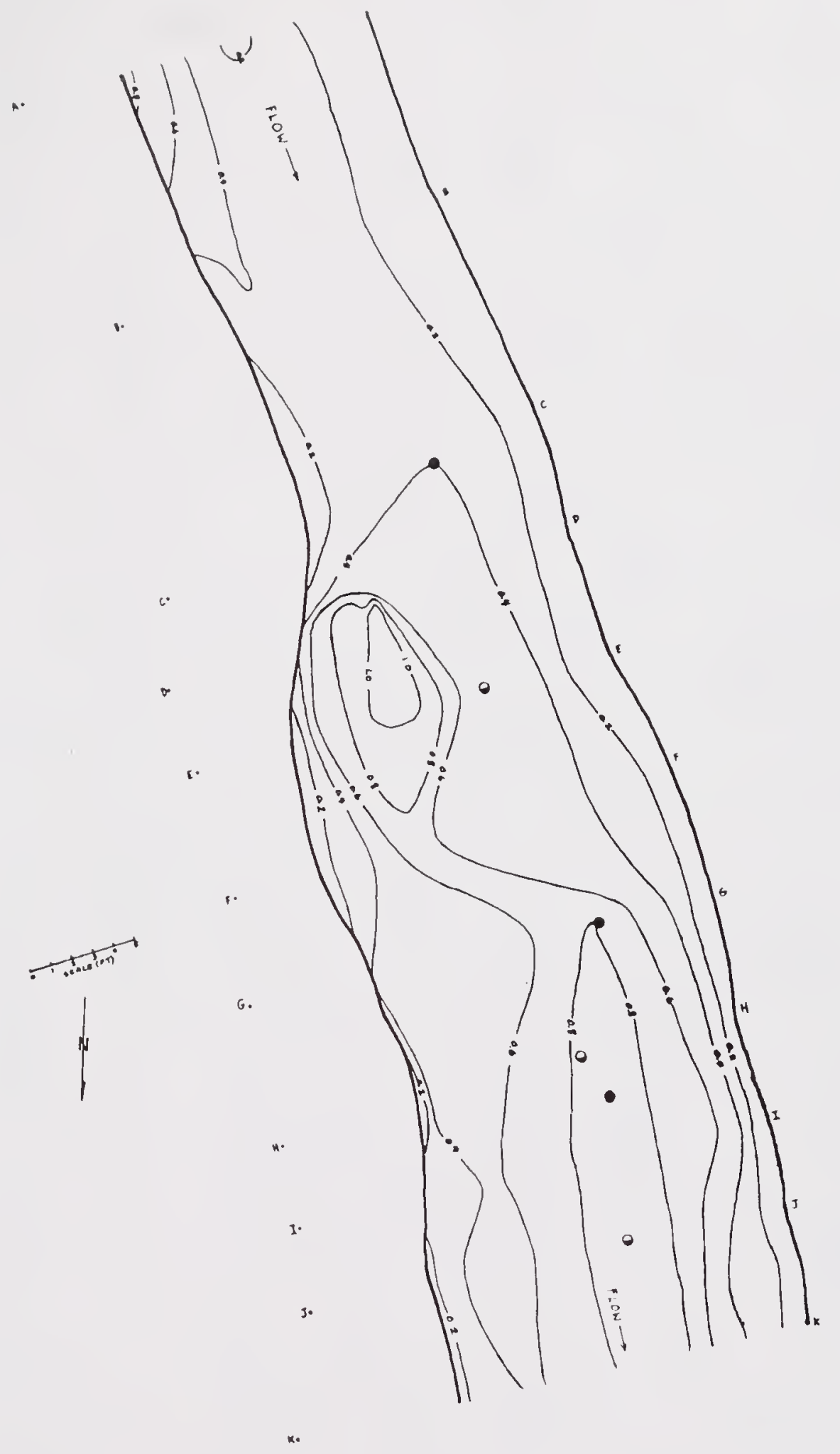

Figure 9. Depth $(f t)$ isopleths for intensive-use area "A" on Swamp Creck. Solid circles and half-solid circles indicate capture sites for Yoy Arctic grayling from the first and second electrofishing surveys, respectively. Letters along streambanks indicate orientation of transects, and letters followed by a period indicate the exact spot from which the transect measurements began. 


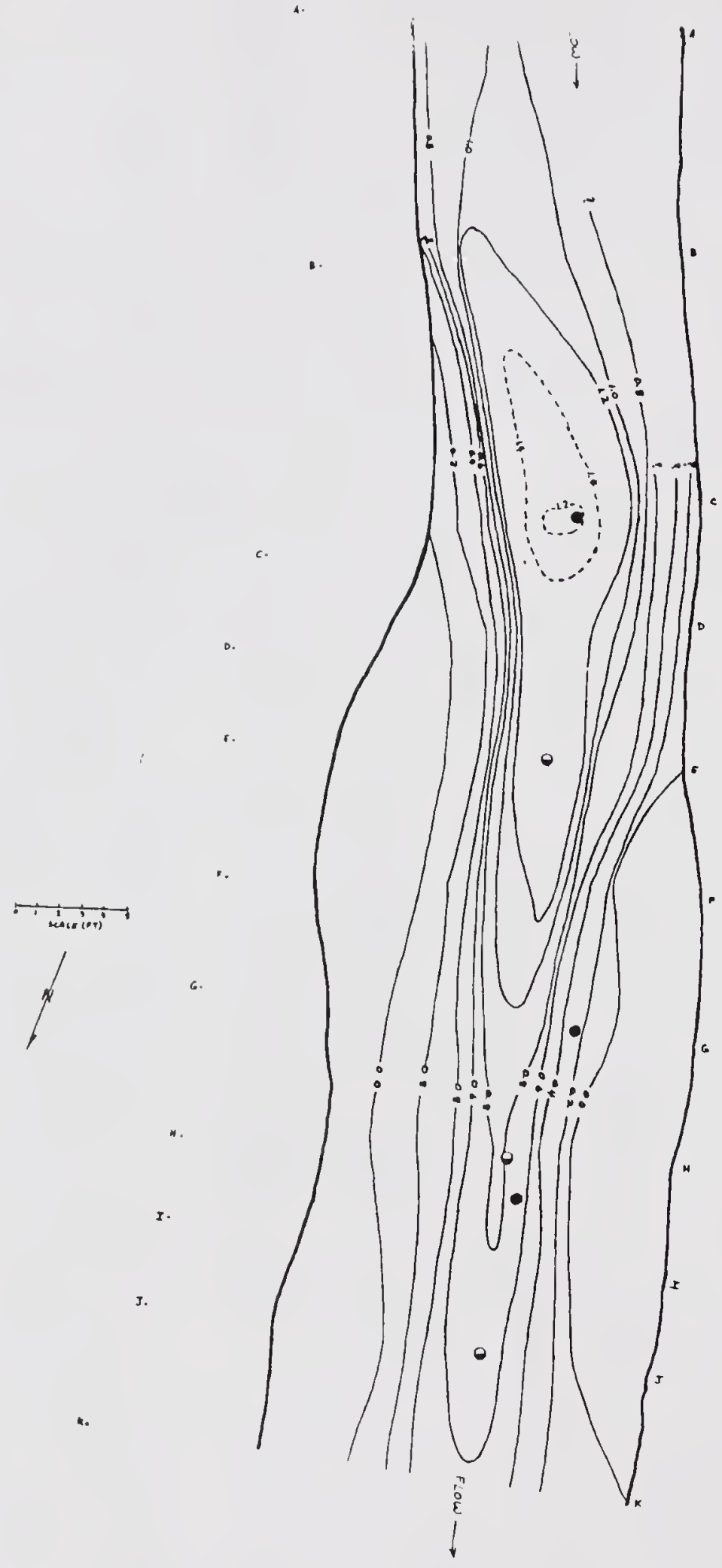

Figure 10. Mean velocity $(\mathrm{ft} / \mathrm{s})$ isopleths for intensive-use area "A" on Swamp Creek. Solid circles and half-solid circles indicate capture sites for YoY Arctic grayling from the first and second electrofishing surveys, respectively. Letters along streambanks indicate orientation of transects, and letters followed by a period indicate the exact spot from which transect measurements began. Dashed lines indicate that location of isopleths are uncertain. 


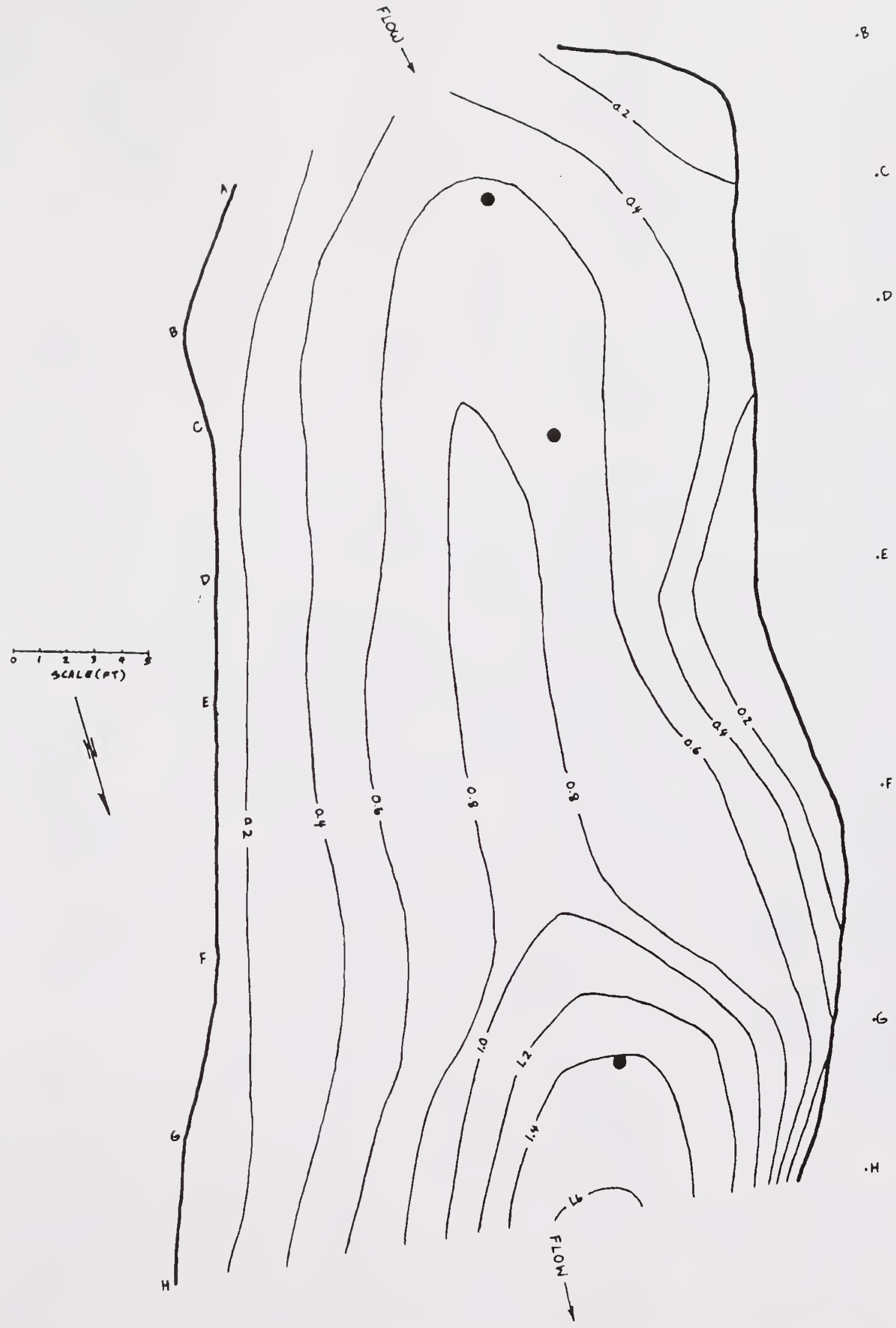

Figure 11. Depth $(f t)$ isopleths for intensive-use area "B" on the Big Hole River. Solid circles indicate capture sites for YOy Arctic grayling from the first electrofishing survey. Letters along streambanks indicate orientation of transects, and letters followed by a period indicate the exact spot from which transect measurenments began. 


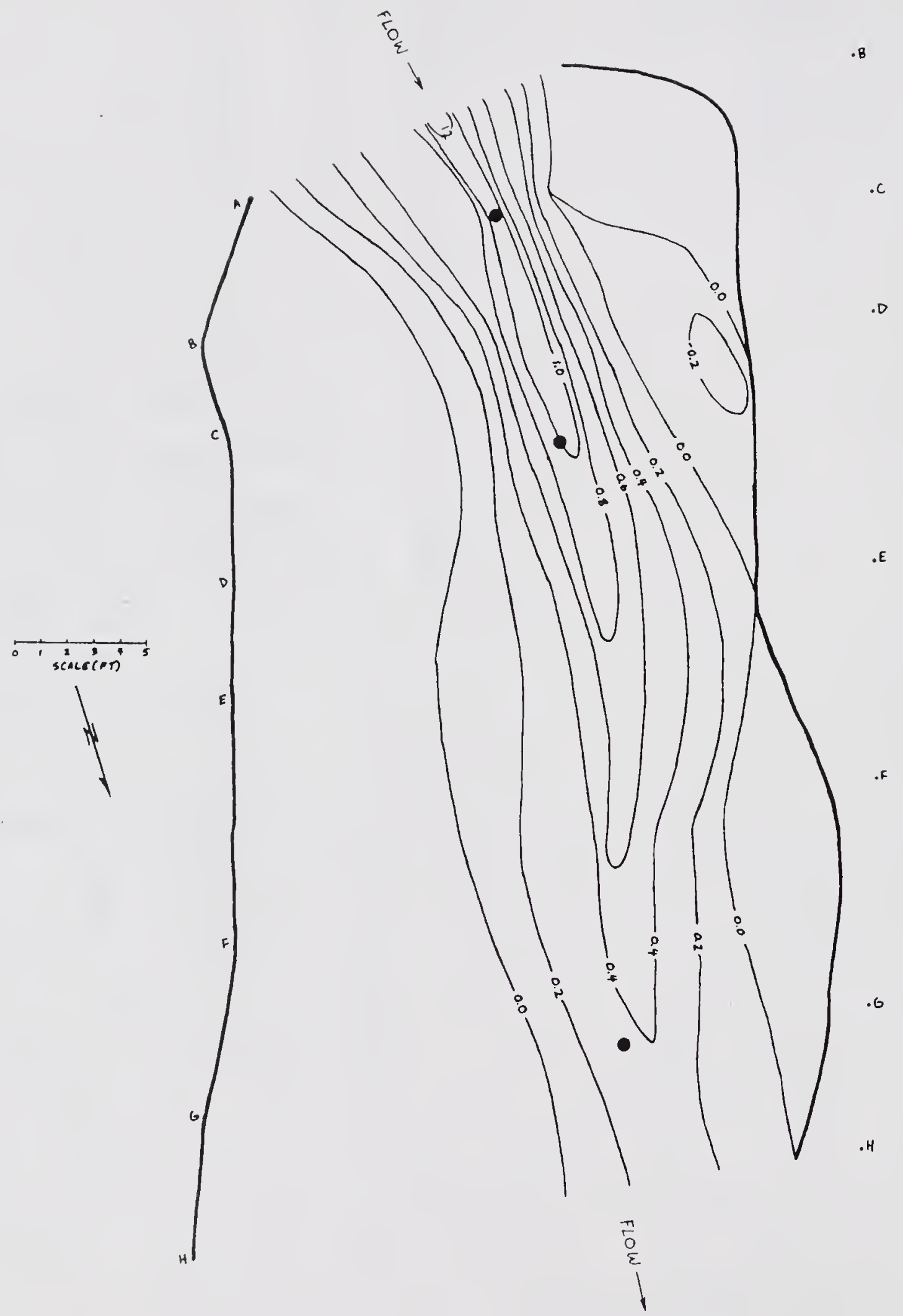

Figure 12. Mean velocity $(\mathrm{ft} / \mathrm{s})$ isopleths for intensive-use area "B" on the Big Hole River. Solid circles indicate capture sitcs for Yor Arctic grayling from the first electrofishing survey. Letters along streambenks indicate orientation of transects, and letters followed by a period indicat the exact spot from which transect measurements began. 


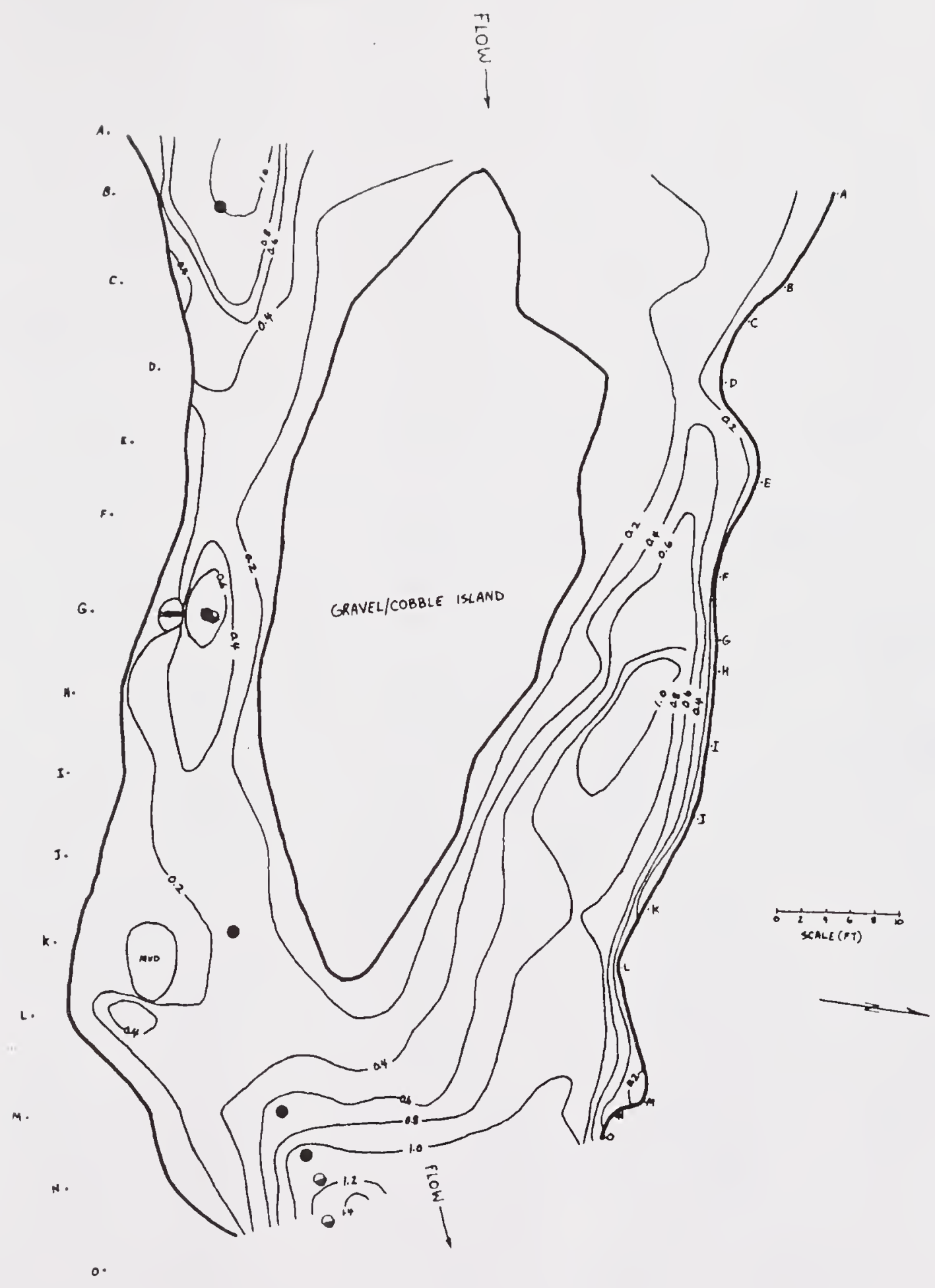

Figure 13. Depth ( $f t$ ) isopleths for intensive-use area "C" on the Big Hole River. Solid circles and half-solid circles indicate capture sites for Yoy Arctic grayling from the first and second electrofishing surveys, respectively. Letters along streambanks indicate orientation of transects, and letters followed by a period indicate the exact spot from which transect measurements began. 


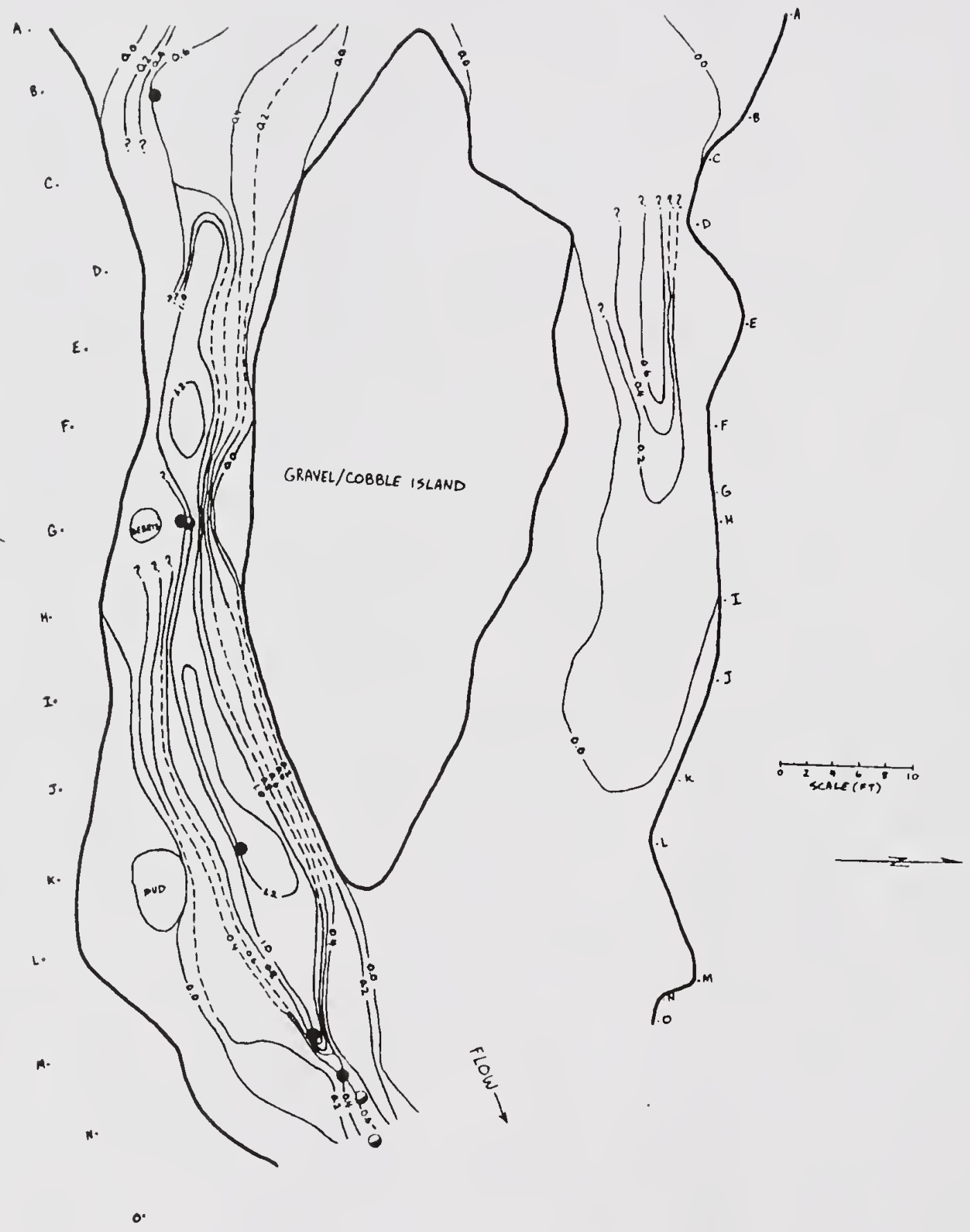

Figure 14.

Mean velocity ( $\mathrm{ft} / \mathrm{s}$ ) isopleths for intensive-use area "C" on the Big Hole River. Solid circles and half-solid circles indicate capture sites for Yoy Arctic grayling from the first and second electrofishing surveys, respectively. Letters along streambanks indicate orientation of transects, and letters followed by a period indicate the exact spot from which transect measurements began. Dashed lines and question marks indicate that location of isopleths are 
I.

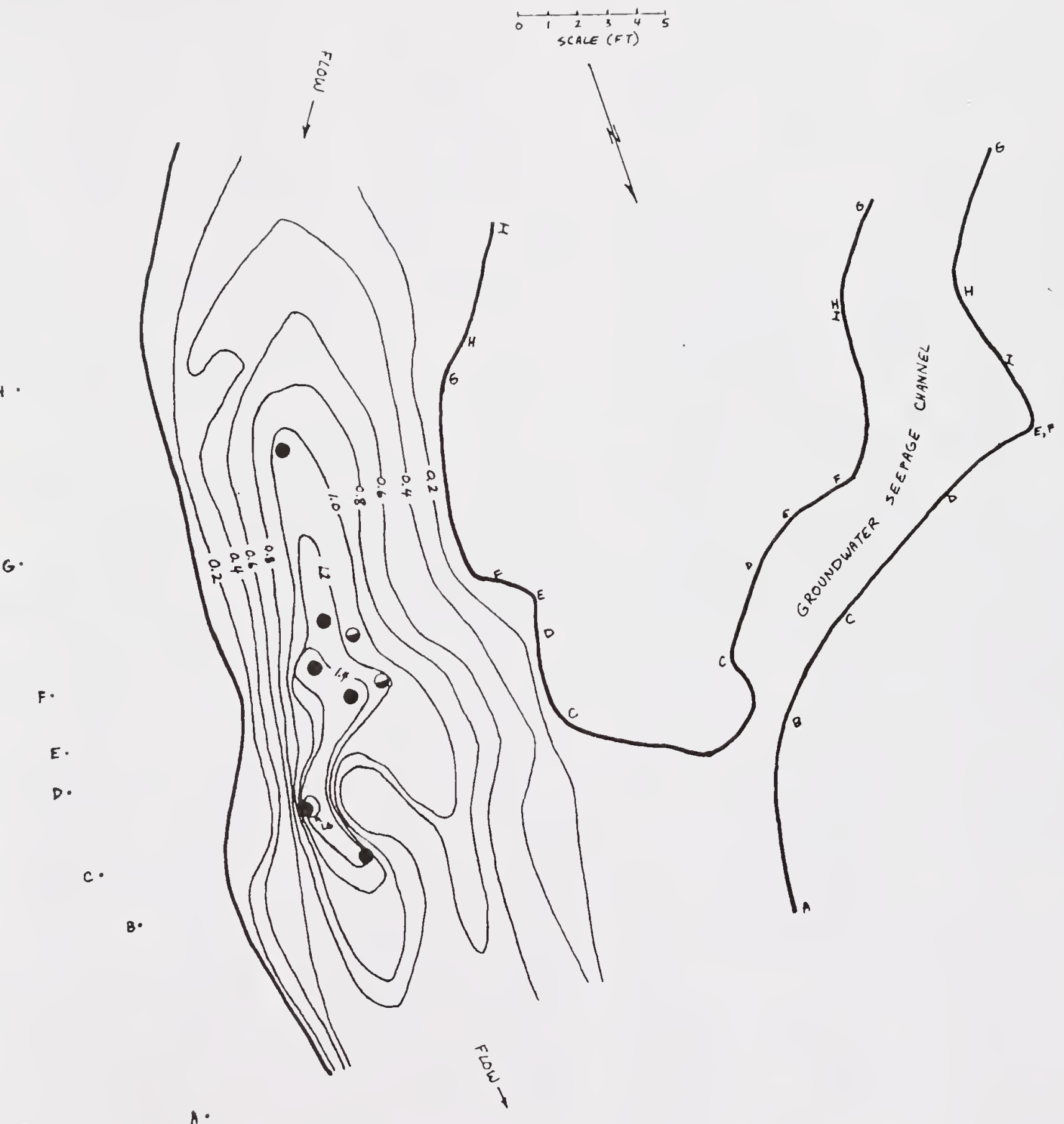

Figure 15. Depth ( $f t$ ) isopleths for intensive-use area "D" on the Big Hole River. Solid circles and half-solid circles indicate capture sites for yor Arctic grayling from the first and second electrofishing surveys, respectively. Letters along strcambanks indicate orientation of transects, and letters followed by a period indicate the exact spot from which transect
measurements began. 


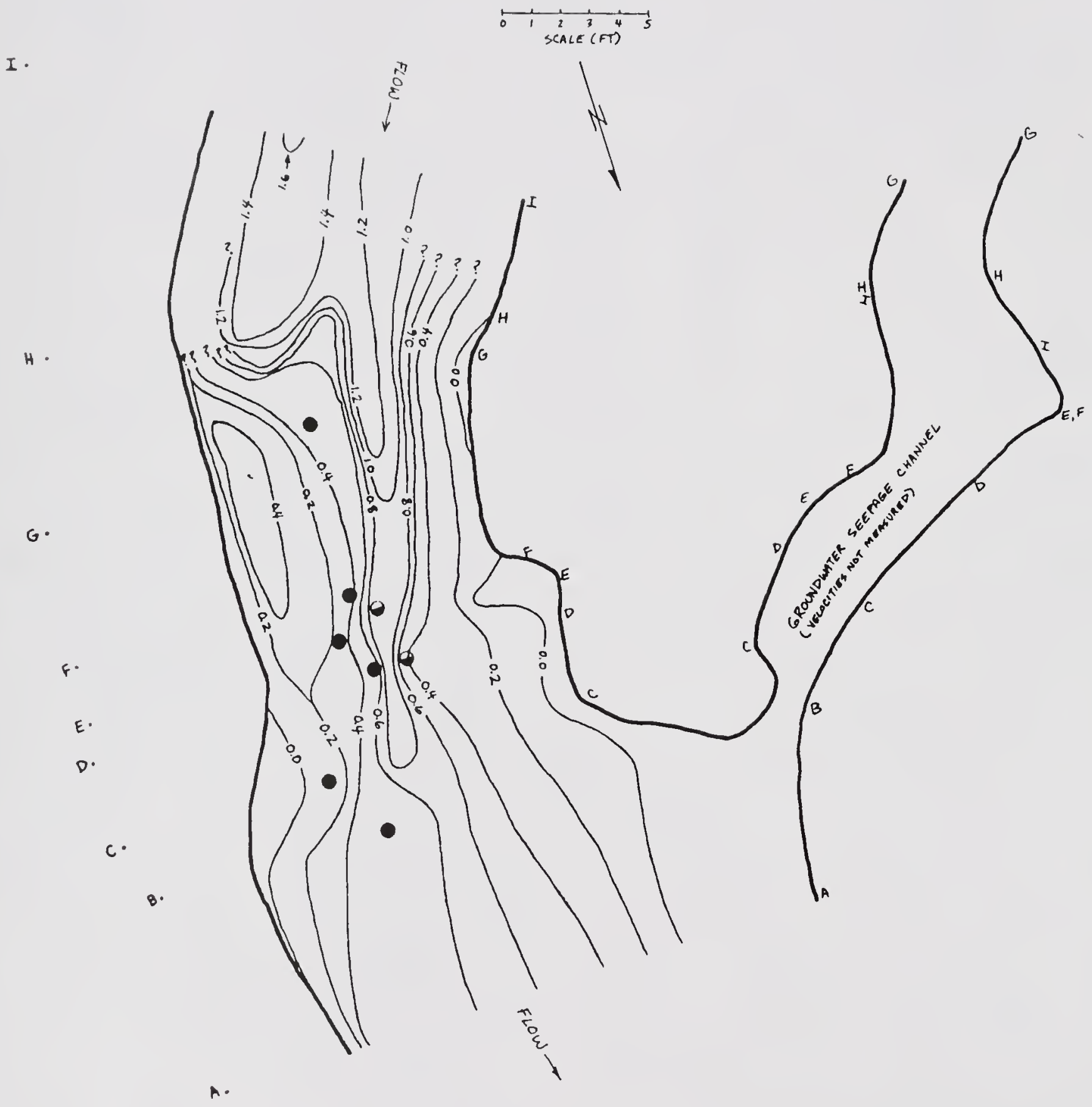

Figure 16.

Mean velocity ( $f t / s)$ isopleths for intensive-use area "D" on the Big Hole River. Solid circles and half-solid circles indicate capture sites for Yoy Arctic grayling from the first and second transects, and surveys, respectively. Letters along strcambanks indicate orientation of measurements began. Question by a period indicate the exact spot from which the transect measurements began. Question marks indicate that lacation of isopleths are uncertain. 


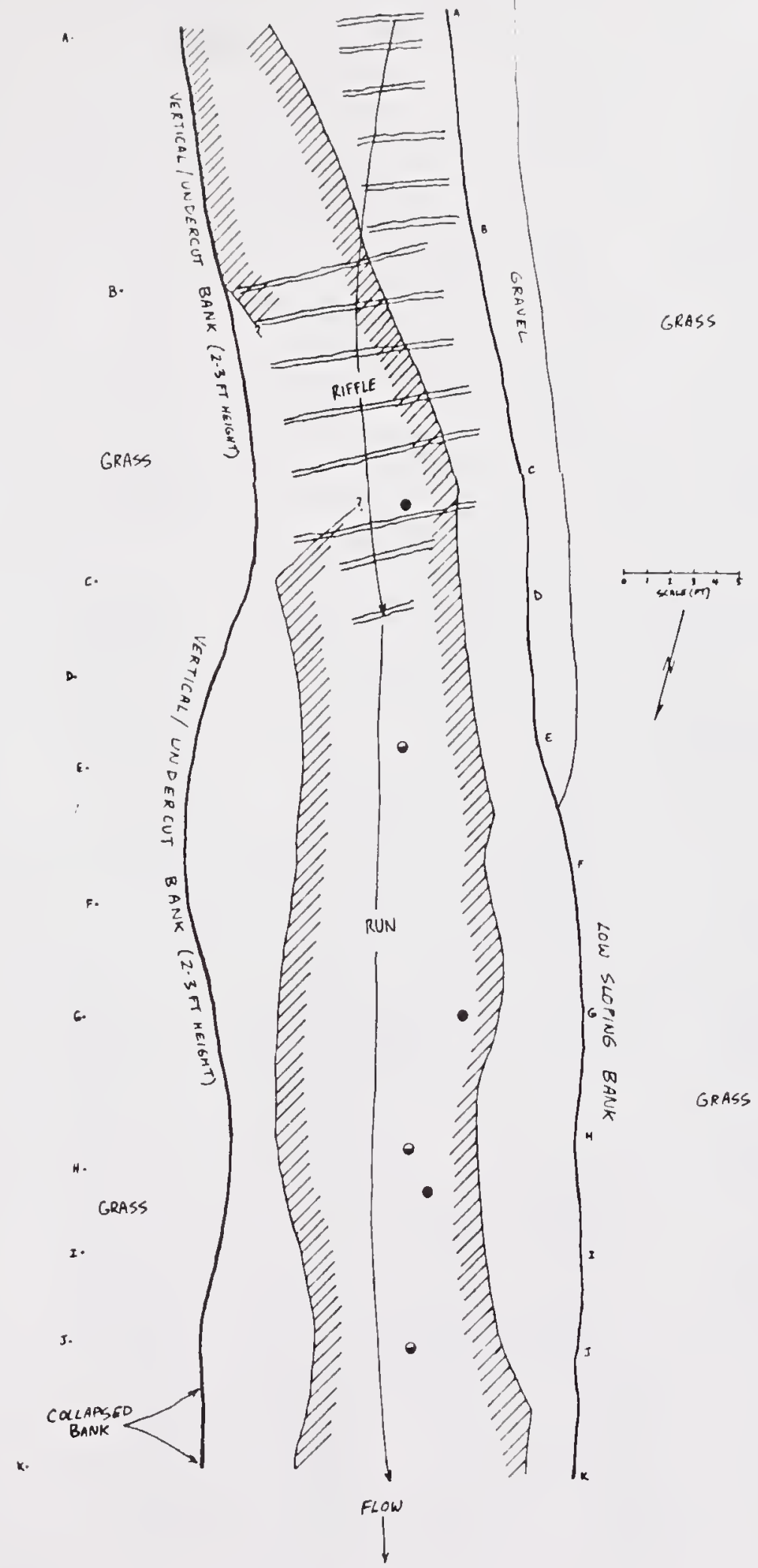

Figure 17. Physical features of intensive-use area "A" on Swamp Creek, indicating usable area (area delimited by shading) for Yor Arctic grayling. Solid circles and half-solid circles indicate capture sites for Yor Arctic grayling from the first and second electrofishing surveys, respectively. 


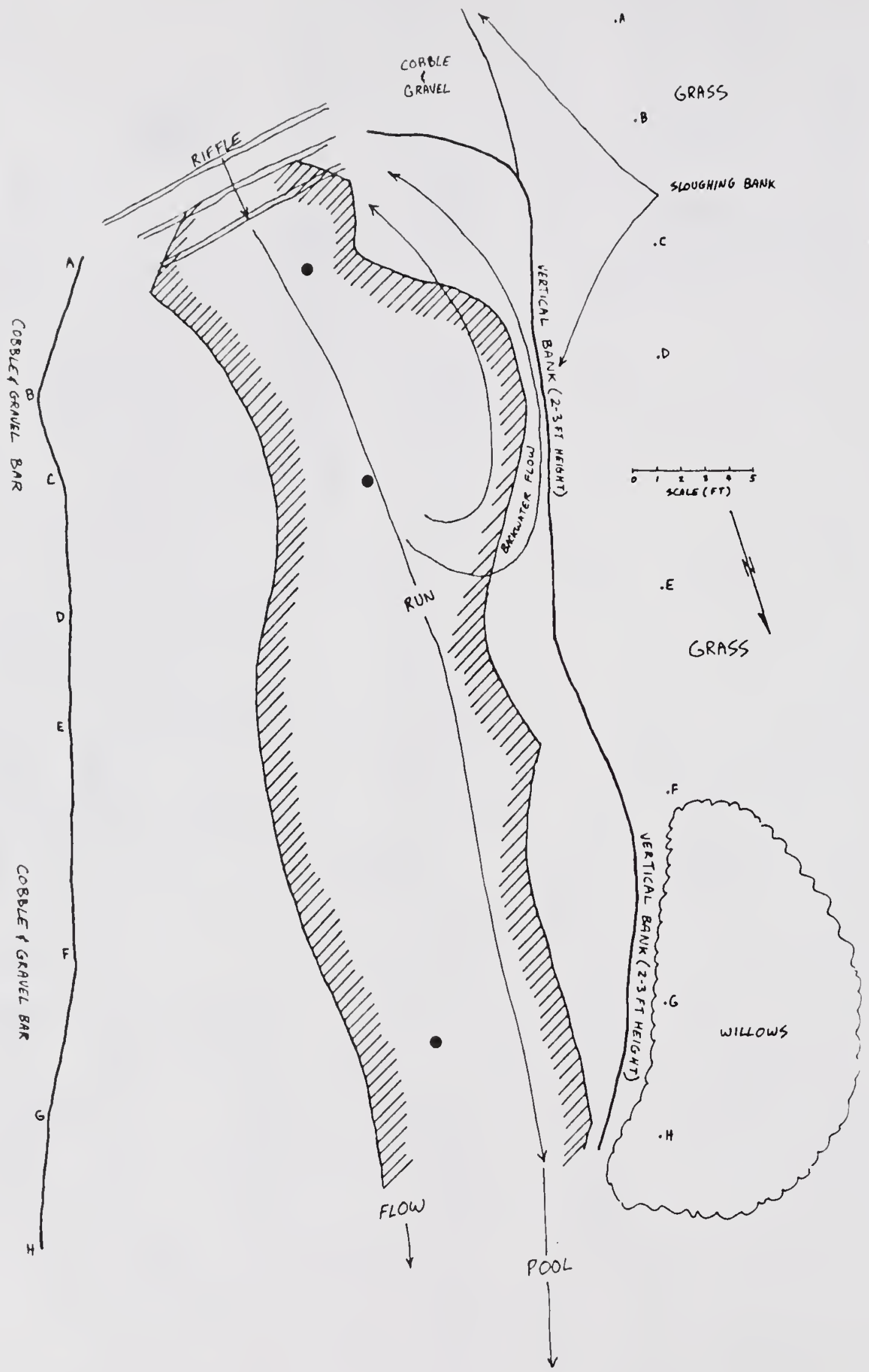

Figure 18. Physical features of intensive-use area "B" on the Big Hole River, indicating usable area (area delimited by shading) for Yoy Arctic grayling. Solid circles and half-solid circles indicate capture sites for Yoy Arctic grayling from the first and second electrofishing surveys, respectively. 


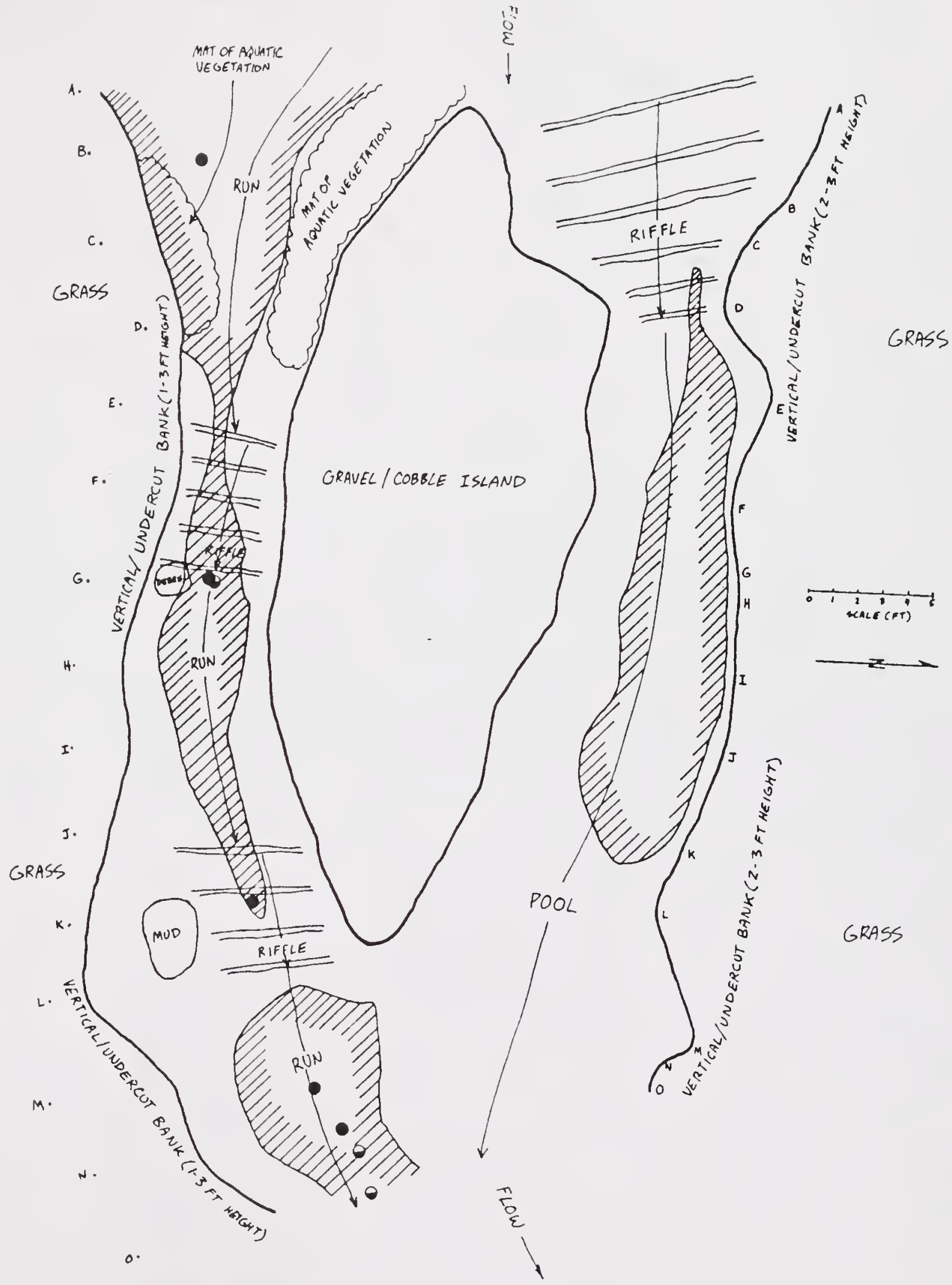

Figure 19. Physical features of intensive-use area "C" on the Big Hole River, indicating usable area (area delimited by shading) for Yoy Arctic grayling. Solid circles and half-solid circles indicate capture sites for Yor Arctic grayling from the first and second electrofishing surveys. 
I.
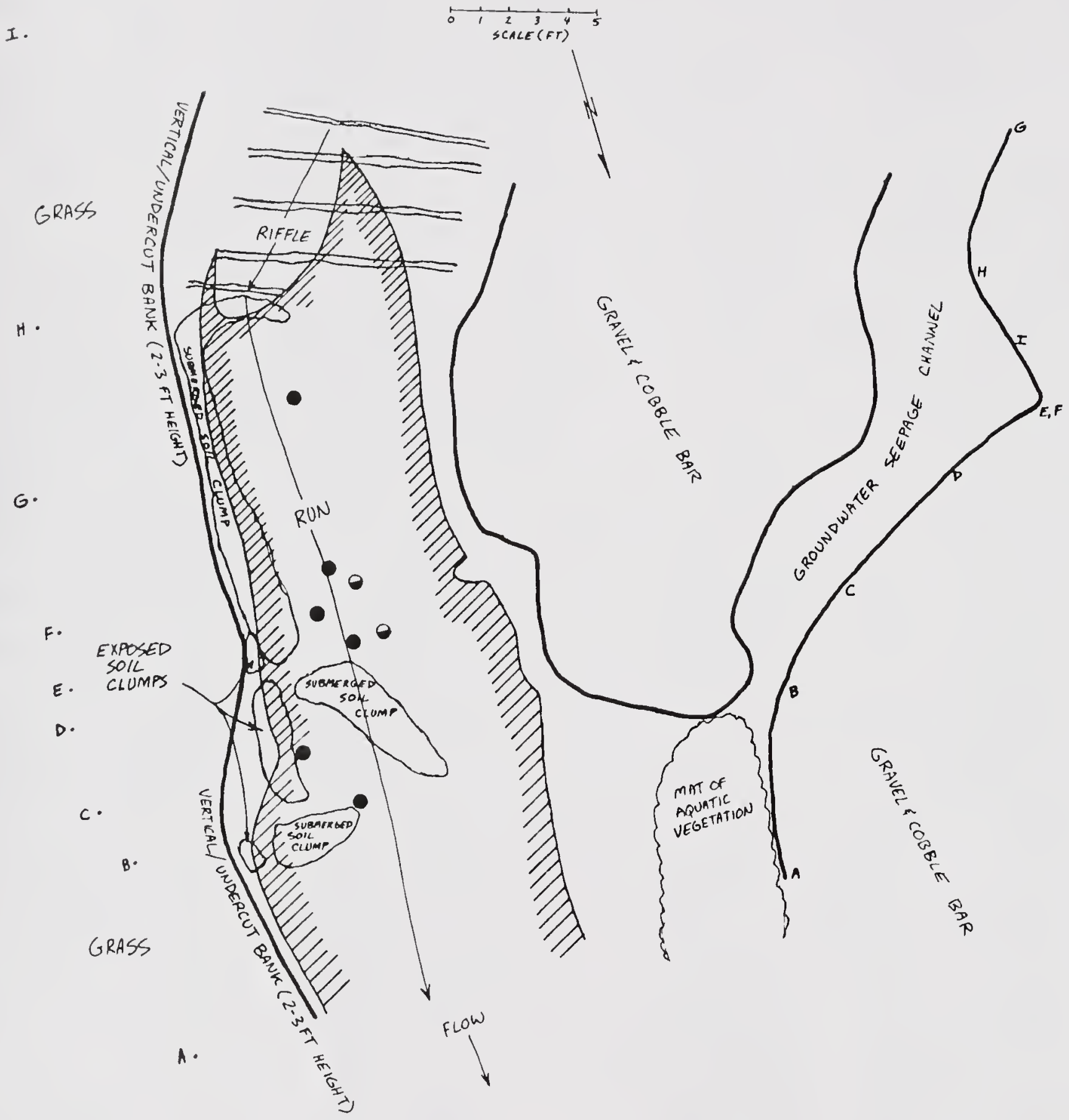

Figure 20.

Physical features of intensive-use area "D" on the Big Hole River, indicating usable area (area delimited by shading) for Yor Arctic grayling. Solid circles and half-solid circles indicate capture sites for Yor Arctic grayling from the first and second electrofishing surveys,
respectively. 
Table 7. Incidence of cover types closest to capture sites and within a $3.28 \mathrm{ft}^{2}$ cell centered on the capture site.

Frequency $(\%)$ with which this cover type was found within

$3.28 \mathrm{ft}^{2}$ area centered

on the capture site.
Frequency $(\%)$ with which this was the closest cover type to the capture site.

\begin{tabular}{|c|c|c|}
\hline Aquatic Vegetation & 84.6 & 86.9 \\
\hline Rock & 8.8 & 4.8 \\
\hline Debris & B.8 & 3.6 \\
\hline Submerged Soil Clump & 6.6 & 1.2 \\
\hline Undercut Bank & 5.5 & 3.6 \\
\hline Turbulence & 2.2 & 0.0 \\
\hline Terrestrial Vegetation & 1.1 & 0.0 \\
\hline
\end{tabular}




\section{Substrate and cover}

All substrate types, except for boulders, were found at the capture sites, although on the average no substrate type predominated (Table 6). All substrate types occupied between 15 and $26 \%$ of the surface area of the streambottom, and silt was estimated to be made up of $21 \%$ organic material (primarily dead algae) and $79 \%$ inorganic material. In many cases, large gravel and cobble were plentiful, but were covered by a thin layer of silt or sand, and were therefore not counted. The substrate at capture sites averaged $53 \%$ embedded, with a range of $39-67 \%$. A comparison of substrate types and levels of embeddedness in both the utilization and availability databases suggests that the fish exhibited a slight preference for larger and less embedded ("cleaner") substrate (Table 6). This is consistent with the preference shown for fast water and riffle/run habitats (Tables 5 and 6), where larger and less embedded substrate predominates.

Cover, on the average, occupied $24 \%$ of the surface area of the streambottom within the $3.28 \mathrm{ft}^{2}$ cell surrounding the capture sites (Table 7). Aquatic vegetation was by far the most abundant type of cover found at the capture sites $(84.6 \%$ of the observations), and was primarily composed of Ranunculus aquatilis and Elodea canadensis. The average distance to cover from capture sites was $0.92 \mathrm{ft}$, and aquatic vegetation was the closest cover type to $86.9 \%$ of the capture sites (Table 7). Information from the availability database shows that the percentage of cover available is roughly similar to that which was utilized, suggesting that there may be no preference for cover within the $3.28 \mathrm{ft}^{2}$ capture site.

\section{Temperature}

Measurements of water temperature were taken throughout the duration of the study. Measurements were taken at irregular intervals, and typically only from mid-morning to early afternoon, so it was usually not possible to determine maximum daily temperatures. Even so, temperatures over $70^{\circ} \mathrm{F}$ were frequently recorded, and the maximum temperature was recorded on July 21 when the Big Hole River reached $79.5^{\circ} \mathrm{F}$ (Table 8). Water temperatures were also recorded at the wisdom Bridge during 1988 by the United States Geological Survey (Shields et al. 1989). The period of record was May 1-July 24, August $12-27$ and September 21-30. The maximum temperature during this period was $76.1^{\circ} \mathrm{F}$ on July 22 , and average daily maximum temperatures were $54.3^{\circ}, 66.6^{\circ}, 72.4^{\circ}, 67.2^{\circ}$, and $56.0^{\circ}$, for the periods of record in May, June, July, August and September, respectively.

The fry stage of Arctic grayling is reported to be the least sensitive to high temperatures (LaPerriere and Carlson 1973, 
Table 8. Maximum daily water temperatures recorded on the Big Hole River and its tributaries, July 12-September 7, 1988.

\begin{tabular}{|c|c|c|c|}
\hline Date & Time & $\begin{array}{l}\text { Location } \\
\text { (Letters refer to } \\
\text { sample sections) }\end{array}$ & Temperature $\left({ }^{\circ} \mathrm{F}\right)$ \\
\hline July 12 & 1645 & $\mathbf{F}$ & 71 \\
\hline July 13 & 1545 & G & 73 \\
\hline July 14 & 1900 & E & 72 \\
\hline July 18 & 1645 & $k$ & 75 \\
\hline July 19 & 1140 & $E$ & 64 \\
\hline July 20 & 1310 & K & 71 \\
\hline July 21 & 1335 & H & 72 \\
\hline July 21 & $1630-2030$ & $\begin{array}{l}\text { Many spots on } \\
\text { Big Hole River } \\
\text { near Wisdom }\end{array}$ & $75 \cdot 79.5$ \\
\hline August 3 & 1345 & $H$ & 63.5 \\
\hline August 4 & 1800 & H & 74 \\
\hline August 8 & 1855 & H & 72 \\
\hline August 9 & 1720 & H & 72 \\
\hline August 10 & 1910 & H & 70 \\
\hline August 15 & 1845 & H & 62 \\
\hline August 16 & 1445 & J & 65 \\
\hline August 17 & 1700 & J & 69 \\
\hline August 18 & 1900 & H & 70 \\
\hline August 23 & 1630 & H & 71 \\
\hline August 24 & 1300 & 1 & 64 \\
\hline August 24 & 1835 & $H$ & 73 \\
\hline August 25 & 1515 & I & 67 \\
\hline August 30 & 1710 & J & 67 \\
\hline September 7 & 1530 & J & 62 \\
\hline
\end{tabular}

Table 9. A comparison of the distance $(f t)$ from capture sites to the base of the nearest upstream riffle when the shocking crew worked upstream vs. downstream. Standard deviations are in parenthesis.

$\begin{array}{lcccc}\text { Situation } & \text { Mean } & \text { Median } & \text { Range } & \begin{array}{c}\text { Number in } \\ \text { sample }\end{array} \\ \text { Working upstream } & 23.2(45.3) & 9.5 & -17.4-296.8^{1} & 79 \\ \text { Working downstream } & 35.1(68.9) & 6.9 & -20.3-196.1^{1} & 12\end{array}$

${ }^{1}$ Negative numbers indicate that capture sites were in riffles. 
cited in Hubert et al 1985). Bioassays showed a median tolerance limit of $76.1^{\circ} \mathrm{F}$ for fry; for juvenile fish $(20 \mathrm{~cm}$ fork

length--approximately the length of age I fish), $100 \%$ survival was seen at $72.5^{\circ} \mathrm{F}$, but $0 \%$ survival at $76.1^{\circ} \mathrm{F}$. Maximum daily temperatures on the Big Hole River were frequently between $72-76^{\circ} \mathrm{F}$ in 1988, suggesting that temperature- caused mortality could have occurred, particularly for age I fish. Studies showing thermal tolerance limits for adult fish were not available for this report, but wojcik (1955, cited in Hubert et al. 1985) found adult grayling to be stressed at $63.0^{\circ} \mathrm{F}$, and to activley avoid $68^{\circ} \mathrm{F}$ water.

\section{Reliability and applicability of microhabitat measurments}

One basic assumption made in this study with regard to habitat- use measurements was that sites at which YoY Arctic grayling were captured were in fact sites at which the fish had chosen to reside, and that the fish had not been displaced by the electrofishing activity. An attempt was made to test this assumption by taking advantage of the fact that the fish seemed to orient to the base of riffles. If fish were displaced or herded away from the electrofishing crew, then it would be expected that, when working upstream, the fish would be pushed toward the bases of the riffles. Conversely, if the crew was working downstream, the fish would be expected to be pushed away from the riffles, and into the pools. A comparison of the distance from the capture site to the base of riffles while working upstream versus downstream was inconclusive, due to the large variations in individual measurements and the small sample size while working downstream (Table 9). While the mean distance from capture site to the base of upstream riffle was somewhat greater when working downstream than when working upstream (35.1 ft and $23.2 \mathrm{ft}$, respectively), the reverse was true with the median distance (6.9 ft and $9.5 \mathrm{ft}$, respectively). It appears that if displacement or herding up-or downstream did occur, it was probably only a short distance. Lateral displacement in the stream--a displacement toward or away from the center of the stream--could not be determined by this comparison, and remains an unknown.

Habitat measurments were taken from 1 day to one month after fish had been captured. During this time interval, the discharge on Swamp Creek and the Big Hole River dropped about $64 \%$ and $22 \%$, respectively. Water levels dropped as well. Based on measurements taken at water- level reference stakes and the discharge measurement stations, water levels on Swamp creek and the Big Hole River were estimated to have dropped $0.12 \mathrm{ft}$ and $0.10 \mathrm{ft}$, respectively. The depth measurements used in the microhabitat analysis therefore have an error up to $0.12 \mathrm{ft}$. The only other habitat variable this error would have an effect on is velocity, and the error could be expected to be greater for 
velocities measured in shallow areas than for velocities measured in pools.

\section{Transferability of utilization criteria to other streams}

It is desirable to know if the utilization criteria developed in Table 6 can be transferred to other areas in the upper Big Hole River drainage. Bovee (1986) provides two rules regarding the tranferability of utilization criteria from one stream to another. First, transferability is most appropriate if the source stream has high diversity and the study stream has low diversity; second, transferability is enhanced if the source and study streams have similar habitat features. Both of the study sites were considered to have fairly high diversity (in terms of types and amounts of pools, riffles and runs, range of depths and velocities, substrate types, amount of cover), but the relative diversity of other streams in the upper Big Hole River drainage is not known. With regard to similarity, there are numerous habitat features these study sites lack that are found elsewhere in the drainage. Rapids, boulders and high water velocities (above $2 \mathrm{ft} / \mathrm{s}$ ) are almost completely lacking in both study sites-habitat features that are common in some locations in the upper portions of the drainage. The streams also have few pools over 4-5 ft deep, few areas dammed by beaver (which provide the combination of deep, slow pools and overhanging bank cover), and very little debris--habitat features that are found in various locations on the Big Hole River downstream from these areas. Transferability based on similarity of habitat types may therefore be somewhat limited.

Bovee (1986) also feels that another useful technique for reviewing transferability is convergence, whereby habitat preference (or utilization) curves are developed on different streams, and if the curves are similar, it helps to confirm that the preference (or utilization) criteria respresent the species throughout a geographical range. In this study, the habitat utilization data from the Big Hole River were statistically compared to similar information from Swamp creek for the possibility of convergence. Mann-Whitney rank tests $(P=0.05)$ were used to to test the null hypothesis that median values for habitat variables on both streams were the same. The null hypothesis was not rejected for tests of depth, mean water velocity, embeddedness, and all substrate types but cobble--but was rejected for cobble and cover. The similarity between most of the habitat variables for the two streams lends some support to the potential for transferability to other streams in the drainage. 
Movements of Young-of-the Year Arctic Grayling in their first summer

Information about the movements of YOY Arctic grayling in their first summer is largely circumstantial. Brad Shepard (MDFWP) surveyed sample sections $\mathrm{H}$ and $\mathrm{J}$ during April and May 1988 for spawning grayling. Ripe or spent fish were found in many locations that were in close proximity to areas where concentrations of YOY fish were found in July and August (Figure 21). This suggests that many fish stayed close to the spawning areas in which they were born, but it is not possible to say if or how many fish moved out of these streams.

The fidelity of the YOY fish to riffle areas was seen when five areas (one on Swamp Creek and four on the Big Hole River) were electrofished for a second time, from 14-29 days after the initial survey. Forty-five YOY Arctic grayling were captured in these areas during the initial survey, while 33 were captured during the second survey. These fish were not marked, so it was not known if they were the same fish that were captured the first time. However, it is significant to note that the fidelity of the fish for these areas continued through a time interval when the streamflow discharge dropped by about $20 \%$ on the Big Hole River and $33 \%$ on Swamp Creek.

\section{Interactions between Arctic grayling and brook trout}

Brook trout have been in the Big Hole River since about 1929, and it has been speculated that their presence has contributed to the decline of the Arctic grayling as a result of predation or competition (Liknes 1981). If interspecific competition for food or space is occurring, spacial segregation might be expected. In this study, distinct differences in habitat use by age It and older fish were seen. Brook trout were most abundant in the higher gradient, upper sample sections of the study Area, but were present throughout the study Area. In the sample sections where both species occured, there was a tendency for brook trout to occupy faster water, often in association with undercut banks or overhanging terrestrial vegetation. The brook trout were not restricted to this type of water, however, and were found in lesser numbers in typical Arctic grayling habitat, which was slow runs or pools with depths typically at least 2-3 ft. Often, the pools could be characterized as backwater areas with foam on the water surface. Nelson (1954) studied these two species in Red Rock Creek, Montana, and found an inverse relationship in the distribution of the two species, suggesting some sort of spatial segregation. In this study, age I+ and older Arctic grayling were usually in such low densities that it was not possible to statistically compare their densities with those of brook trout. 
species to use different types of habitat. In the areas where high densities of Arctic grayling were found (sample sections $\mathrm{H}$ and $J)$, brook trout tended to occupy a wider range of habitats than did the grayling fry. They used areas that ranged from slow, shallow runs to fast riffles, and were sometimes found far from cover, while at other times were in close association with aquatic vegetation or undercut banks. 


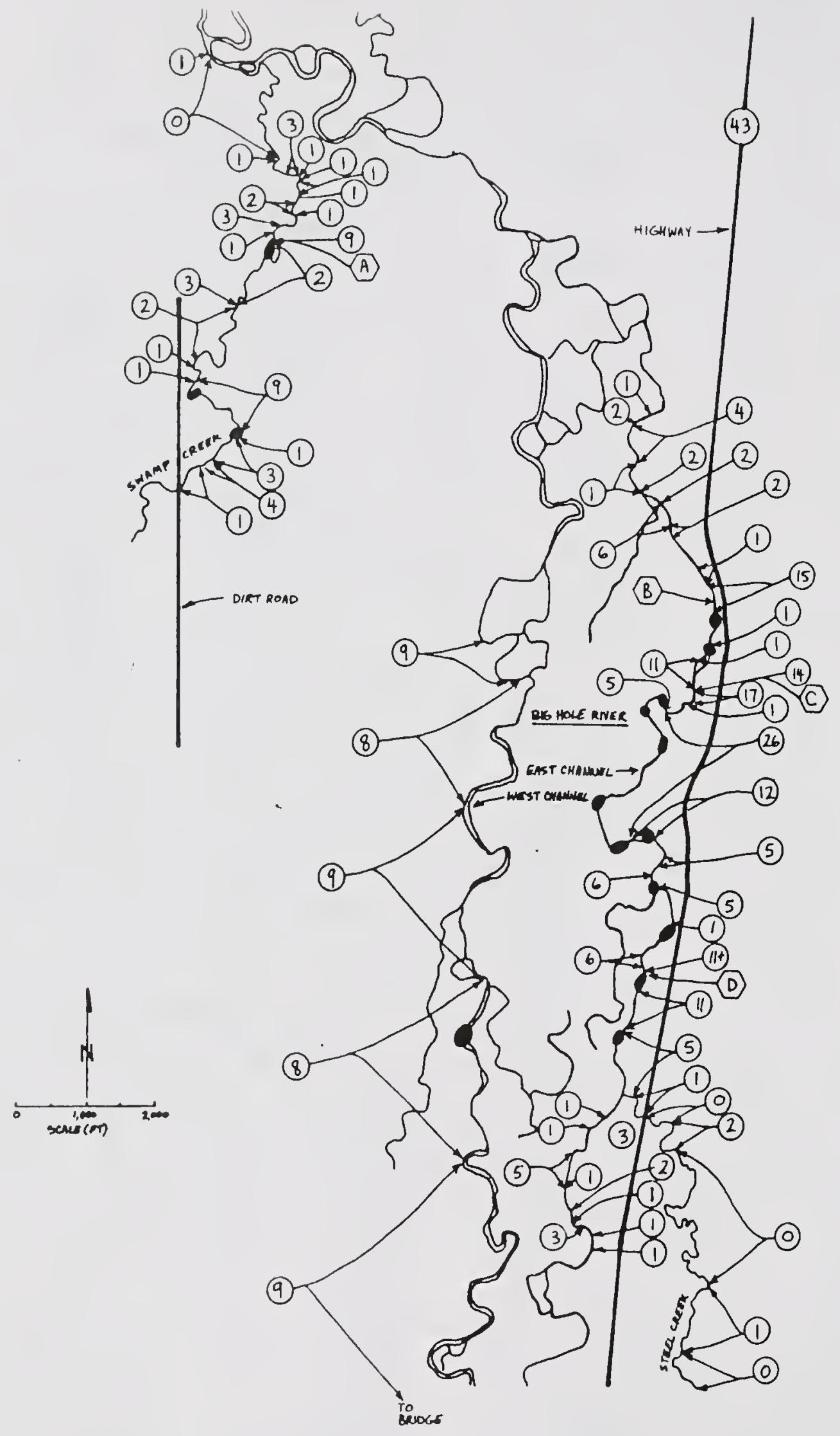

Figure 21.

Locations where young-of-the-year Arctic grayling were captured in Swamp Creck and the cast channel of the Big Hole River during July and August 1988 (open circles, which include number of May 1988 (blackened areas). Letters in hexagons indicate the location of intensive-use areas. 
Occasionally both species were found utilizing the same areas. The possibility that spatial segregation was occurring was investigated by performing linear regression analysis on the abundance of the two species in sub-sections where both species occurred (Figure 22). Although the correlation was not significant $(r=-0.18, P>0.05, d . f .=54)$, the scatterplot shows that there was a tendency for one of the species to be in low numbers if the other species was in high numbers.

The outcome of social interactions between brook trout and Arctic grayling fry--such as spatial segregation--would probably be dependent, in part, on the size difference between the two species. Brook trout fry would normally be expected to have a size advantage over grayling fry because they emerge between February and April (Brown, 1971), and are already one or two months old by the time grayling emerge. In this study, the size advantage of brook trout was quickly lost; by July 20-21 the Arctic grayling were already longer than brook trout (Table 4 , Figure 3), and retained this size advantage until at least August 16-17, the last date the lengths of the two species were compared.

Predation of brook trout fry on Arctic grayling fry has been reported by Nelson (1954) who found grayling fry in the stomachs of 2-4-inch brook trout in Red Rocks Creek, Montana in late June. The most likely time for predation to occur seems to be shortly after emergence of grayling fry. The fry are very small during this time (Lund [1974] found emigrating fry as small as 0.55 inches in the Red Rock River drainage, Montana) and the size difference between the two species is at its greatest. The possibility of predation was not investigated in this study. 


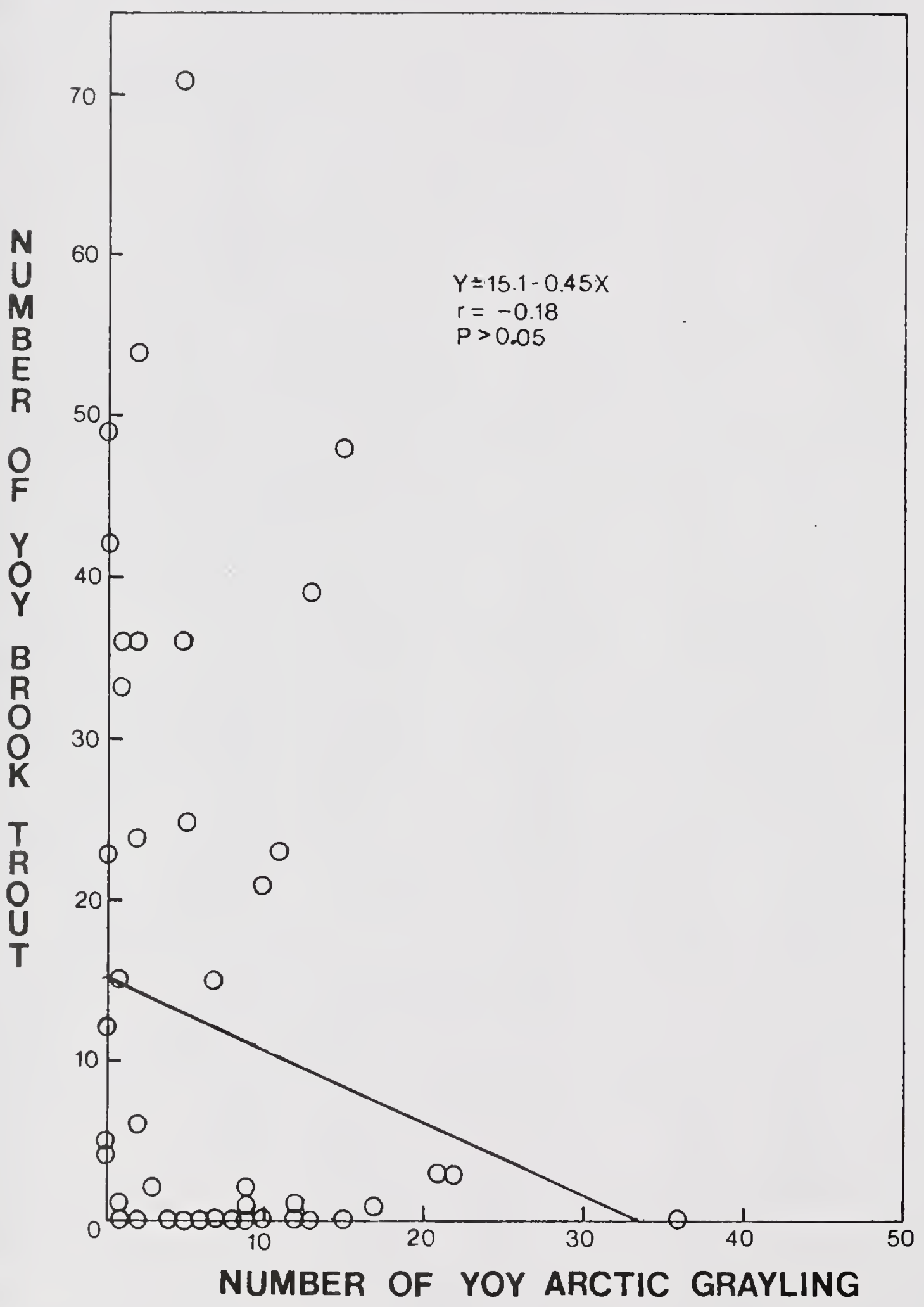

Figure 22. Scatterplot and linear regression of number of young-of-the-year brook trout vs. number of young-of-the-year Arctic grayling. 


\section{LITERATURE CITED}

Bovee, K.D. 1986. Development and evaluation of habitat suitability criteria for use in the Instream Flow Incremental Methodology. Instream Flow Information Paper 21. U.S. Fish Wildl. Serv. Biol. Rep. 86(7). $235 \mathrm{pp}$.

Brown, C.J.D. 1971. Fishes of Montana. Big Sky Books, Montana state University, Bozeman. 207 pp.

Hubert, W.A., R.S. Helzner, L.A. Lee and P.C. Nelson. 1985. Habitat suitability index models and instream flow suitability curves: Arctic grayling riverine populations. U.S. Fish and Wildife Service. Biological Report 82 (10.110).

LaPerriere, J.D. and R.F. Carlson. 1973. Thermal tolerances of interior Alaskan arctic grayling, Thymallus arcticus. Inst. Water Resour. Rep. IWR-46. Univ. Alaska, Fairbanks.

Liknes, G.A. 1981. The fluvial Arctic grayling (Thymallus arcticus) of the upper Big Hole River drainage, Montana. M.S. Thesis, Montana State University, Bozeman. 59 pp.

Lund, J.A. 1974. The reproduction of salmonids in the inlets of Elk Lake, Montana. M.S. Thesis, Montana State University, Bozeman. $43 \mathrm{pp}$.

Nelson, P.H. 1954. Life history and management of the American grayling (Thymallus signifer tricolor) in Montana. Jour. Wildl. Mgt. 18(3):324-342.

Shepard, B.B. 1989. Timing, location and population characteristics of spawning Montana Arctic grayling (Thymallus arcticus montanus [Milner]) in the Big Hole River drainage, 1988. Montana Department of Fish, Wildlife and Parks, Bozeman. $38 \mathrm{pp}$.

Shields, R.R., J.R. Knapton, M.K. White, T.M. Brosten, and J.H. Lambing. 1989. Water Resources Data. Montana. Water Year 1988. U.S. Geological Survey. Water Data Report MT-88-1.

Wojcik, F. 1955. Life history and management of the grayling in interior Alaska. M.S. Thesis, University of Alaska, Fairbanks. 54 pp. 

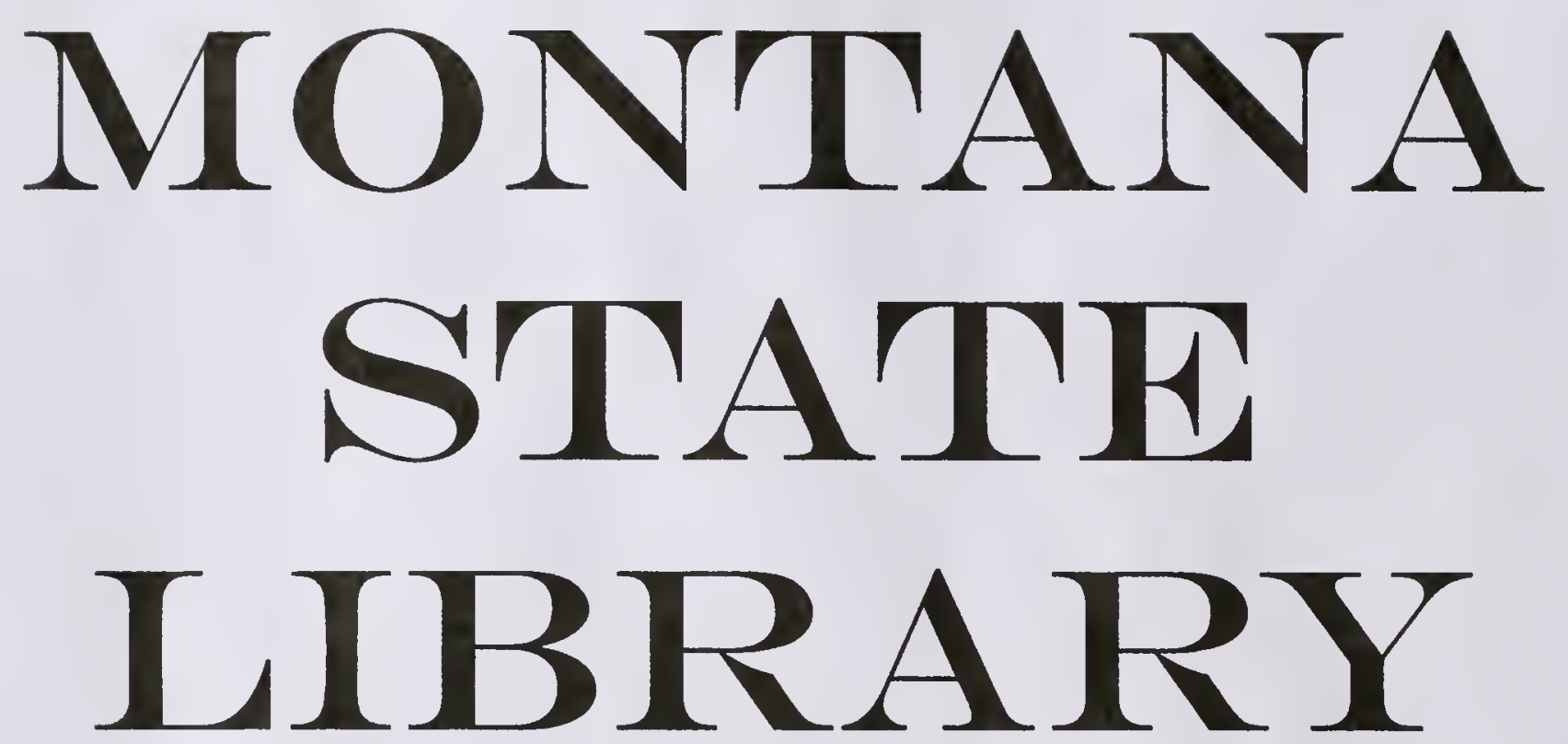